\title{
Molecular, Morphological, and Functional Characterization of Corticotropin-Releasing Factor Receptor 1-Expressing Neurons in the Central Nucleus of the Amygdala
}

\author{
S. A. Wolfe," H. Sidhu," R. R. Patel," M. Kreifeldt, S. R. D’Ambrosio, ㄷ. Contet," and M. Roberto"
}

https://doi.org/10.1523/ENEURO.0087-19.2019

Department of Neuroscience, The Scripps Research Institute, La Jolla, CA 92037

\begin{abstract}
The central nucleus of the amygdala $(\mathrm{CeA})$ is a brain region implicated in anxiety, stress-related disorders and the reinforcing effects of drugs of abuse. Corticotropin-releasing factor (CRF, Crh) acting at cognate type 1 receptors $\left(\mathrm{CRF}_{1}, \mathrm{Crhr} 1\right)$ modulates inhibitory and excitatory synaptic transmission in the CeA. Here, we used $\mathrm{CRF}_{1}$ :GFP reporter mice to characterize the morphological, neurochemical and electrophysiological properties of $\mathrm{CRF}_{1}$ expressing $\left(\mathrm{CRF}_{1}+\right)$ and $\mathrm{CRF}_{1}$-non-expressing $\left(\mathrm{CRF}_{1}-\right)$ neurons in the $\mathrm{CeA}$. We assessed these two neuronal populations for distinctions in the expression of GABAergic subpopulation markers and neuropeptides, dendritic spine density and morphology, and excitatory transmission. We observed that $\mathrm{CeA} \mathrm{CRF}_{1}+$ neurons are GABAergic but do not segregate with calbindin (CB), calretinin (CR), parvalbumin (PV), or protein kinase C- $\delta(\mathrm{PKC} \delta)$. Among the neuropeptides analyzed, Penk and Sst had the highest percentage of co-expression with Crhr1 in both the medial and lateral $\mathrm{CeA}$ subdivisions. Additionally, $\mathrm{CeA} \mathrm{CRF}{ }_{1}+$ neurons had a lower density of dendritic spines, which was offset by a higher proportion of mature spines compared to neighboring $\mathrm{CRF}_{1}$ - neurons. Accordingly, there was no difference in basal spontaneous glutamatergic transmission between the two populations. Application of CRF increased overall vesicular glutamate release onto both $\mathrm{CRF}_{1}+$ and $\mathrm{CRF}_{1}$ - neurons and does not affect amplitude or kinetics of EPSCs in either population. These novel data highlight important differences in the neurochemical make-up and morphology of $\mathrm{CRF}_{1}+$ compared to $\mathrm{CRF}_{1}-$ neurons, which may have important implications for the transduction of CRF signaling in the CeA.
\end{abstract}

Key words: calcium binding proteins; corticotropin-releasing factor; dendritic spines; glutamatergic signaling; neuropeptides; stress and anxiety

\section{Significance Statement}

Corticotropin-releasing factor (CRF) is involved in emotional regulation via hypothalamic and amygdalar circuits, and is implicated in several psychiatric disorders including anxiety, depression, addiction, posttraumatic stress disorder, and eating disorders. Our novel identification of specific molecular, morphologic and functional properties to distinguishing CRF receptor type $1\left(\mathrm{CRF}_{1}\right)+$ neurons in the central amygdala represents a critical step in understanding the cellular role and dysregulation of the CRF system in pathologic conditions.

Received March 8, 2019; accepted May 25, 2019; First published June 5, 2019.

The authors declare no competing financial interests.
Author contributions: S.A.W., H.S., R.R.P., M.K., S.R.D., and C.C. performed research; S.A.W., H.S., R.R.P., C.C., and M.R. analyzed data; S.A.W., R.R.P., and M.R. wrote the paper; C.C. and M.R. designed research; M.R. contributed unpublished reagents/analytic tools. 


\section{Introduction}

The corticotropin-releasing factor (CRF, Crh) plays an important role in emotional regulation via hypothalamic and amygdalar circuits under normal physiologic conditions (Heilig et al., 1994). Accordingly, dysregulation of the CRF system is implicated in several animal models of psychiatric disorders. Despite promising preclinical studies in animal models including anxiety, depression, addiction, posttraumatic stress disorder, and eating disorders (Menzaghi et al., 1994; Koob, 2003, 2008; Valdez et al., 2003; Chu et al., 2007; Funk et al., 2007; Ciocchi et al., 2010; Bruijnzeel et al., 2012; lemolo et al., 2013; Ji et al., 2013; Baiamonte et al., 2014; Tye et al., 2011). The clinical studies of CRF receptor type $1\left(\mathrm{CRF}_{1}\right)$ antagonists on mood disorders have been unsuccessful (Zorrilla and Koob, 2004; Nielsen, 2006; Heilig et al., 2011; Kwako et al., 2015; Schwandt et al., 2016; Dunlop et al., 2017). It has been suggested that these differences may be due to several factors including differences between human symptomatology compared to animal behavior, differences in contributions of different $\mathrm{CRF}_{1}$ populations, or functional state of $\mathrm{CRF}_{1}$ between humans and animals, and dosage and bioavailability of the $\mathrm{CRF}_{1}$ antagonists (Zorrilla and Koob, 2004; Nielsen, 2006; Binneman et al., 2008; Kehne and Cain, 2010; Cruces et al., 2014; Dong et al., 2018). Despite these pitfalls, further research is needed to understand more mechanistically the CRF/ $\mathrm{CRF}_{1}$ system which could develop $\mathrm{CRF}_{1}$ antagonists to be suitable for patient treatment with improved bioavailability and decreased side-effects in humans (Pomrenze et al., 2017; Spierling and Zorrilla, 2017; Dong et al., 2018).

$\mathrm{CRF}$ and $\mathrm{CRF}_{1}(\mathrm{Crhr}$ ) expressing neurons are located in several brain regions including the central nucleus of the amygdala $(\mathrm{CeA})$, which functions as the main output nucleus for amygdala functions (Gilpin et al., 2015). The $\mathrm{CeA}$ is comprised of medial (CeM) and lateral (CeL) subdivisions (Sun et al., 1991; Petrovich et al., 1996; Dong et al., 2001; Ciocchi et al., 2010; Davis et al., 2010; Haubensak et al., 2010; McCullough et al., 2018) and contains mostly GABAergic projection neurons and interneurons (Sun and Cassell, 1993; Veinante and FreundMercier, 1998). The CeM sends inhibitory projections to various effector regions [e.g., hypothalamus, periaqueductal gray, locus coeruleus, bed nucleus of the stria terminalis (BNST), and pedunculopontine tegmental nu-

This work was supported by the Pearson Center for Alcoholism and Addiction Research and by National Institute on Alcohol Abuse and Alcoholism/National Institutes of Health Grants AA021491, AA015566, AA006420, AA017447, AA026685, AA024952, F32: AA026865, T32: AA007456, and U01 AA013498.

*S.A.W., H.S., R.R.P., C.C., and M.R. These authors contributed equally.

Acknowledgements: We thank Dr. Nick Justice for providing CRF :GFP $_{1}$ breeders. This is manuscript number 29813 from The Scripps Research Institute.

Correspondence should be addressed to M. Roberto at mroberto@ scripps.edu.

https://doi.org/10.1523/ENEURO.0087-19.2019

Copyright (C) 2019 Wolfe et al.

This is an open-access article distributed under the terms of the Creative Commons Attribution 4.0 International license, which permits unrestricted use, distribution and reproduction in any medium provided that the original work is properly attributed. cleus; Pitkänen and Amaral, 1994]. The CeL sends inhibitory inputs to CeM, thereby gating the output activity of the $\mathrm{CeA}$, but also to more distant brain regions such as the periaqueductal gray and paraventricular nucleus of the thalamus (Penzo et al., 2014).

Accumulating evidence implicates the $\mathrm{CRF}_{\mathrm{CRF}}$ system in the $\mathrm{CeA}$ in many animal models of physiological and pathological conditions (Chu et al., 2007; Funk et al., 2007; Roberto et al., 2010; Bruijnzeel et al., 2012; LoweryGionta et al., 2012; lemolo et al., 2013; Ji et al., 2013; Baiamonte et al., 2014). However, cellular heterogeneity in this region has limited the identification and full functional characterization of the $\mathrm{CRF}_{1}$-expressing $\left(\mathrm{CRF}_{1}+\right)$ subset. Thus, we used a bacterial artificial chromosome (BAC) transgenic mouse line expressing the green fluorescent protein (GFP) under the Crhr1 promoter $\left(\mathrm{CRF}_{1}: \mathrm{GFP}\right)$ to readily identify neurons expressing $\mathrm{CRF}_{1}$ (Justice et al., 2008). Previously $\mathrm{CRF}_{1}+$ neurons were observed to be mainly located in the CeM and exhibit an ongoing tonic GABAergic conductance driven by action potential-dependent GABA release. In contrast, $\mathrm{CRF}_{1}$ non-expressing $\left(\mathrm{CRF}_{1}-\right)$ neurons display no ongoing tonic inhibition (Herman et al., 2013). Although this functional analysis has yielded significant insight into cell type-specific properties in CeA microcircuits, a precise molecular characterization of the $\mathrm{CRF}_{1}+$ neuronal population is lacking.

The expression pattern of several relevant markers in the rat and mouse CeA have been used to distinguish neuronal subsets including: calcium-binding proteins (CBPs; Andressen et al., 1993; Kemppainen and Pitkänen, 2000), neuropeptides such as CRF (Petrovich et al., 1996), somatostatin (Sst; Li et al., 2013; Penzo et al., 2014; Yu et al., 2016; Kim et al., 2017), proenkephalin (PENK, Penk; Poulin et al., 2008), prodynorphin (PDYN, Pdyn; Merchenthaler et al., 1997; Funk et al., 2006; Schwarzer, 2009), neuropeptide Y (NPY, Npy; Lin et al., 2006; McGuire et al., 2011; Gilpin et al., 2015), and protein kinase $\mathrm{C}-\delta$ (PKC- $\delta$, Prkcd; Herry et al., 2008; Haubensak et al., 2010; Cai et al., 2014). However, the patterns of co-expression of these markers with Crhr1 are unknown.

Given the critical role of $\mathrm{CRF}$ and $\mathrm{CRF}_{1}$ in the $\mathrm{CeA}$, we sought to identify unique molecular, morphologic and functional properties that distinguish $\mathrm{CeA} \mathrm{CRF}_{1}+$ neurons from their $\mathrm{CRF}_{1}$ - neighbors. Utilizing $\mathrm{CRF}_{1}$ :GFP mice we determined the following characteristics of $\mathrm{CeA} \mathrm{CRF}_{1}+$ and $\mathrm{CRF}_{1}$ - neurons: (1) co-expression patterns of $\mathrm{CRF}_{1}$ (via GFP reporter) with CBPs parvalbumin (PV), calretinin (CR), and calbindin (CB); (2) co-expression patterns of Crhr1 with Penk, Pdyn, Sst, Npy, Crh, and Prkcd; (3) dendritic spine morphology and density; and (4) basal and CRF-modulated glutamatergic transmission. We found that Penk and Sst have the highest percentage of coexpression with Crhr1 in both the CeM and CeL, and that Penk is enriched in CeM Crhr1 + neurons compared to their Crhr1- neighbors. We also show that $\mathrm{CeM} \mathrm{CRF}_{1}+$ neurons exhibit an overall lower spine density and differential fractions of mature versus immature spines compared to $\mathrm{CRF}_{1}$ - neurons. Consistent with a comparable density of mature spines in these two populations, we found no difference in spontaneous EPSCs (sEPSCs) or 
miniature EPSCs (mEPSCs). Importantly, acute CRF application increased overall CeM glutamatergic transmission and does not affect amplitude or kinetics of EPSCs in either population. These data provide important information about the neurobiology of $\mathrm{CeA} \mathrm{CRF}_{1}+$ neurons that may have critical implications for their functional role under physiological and pathological conditions.

\section{Materials and Methods}

All procedures were approved by our Institutional Animal Care and Use Committee and were consistent with the National Institutes of Health Guide for the Care and Use of Laboratory Animals. Transgenic $\mathrm{CRF}_{1}$ :GFP mice were generated on a mixed C57BL/6J x BALB/c background using BAC recombination (see Justice et al., 2008 for transgene design and immunohistochemical validation of reporter expression). A colony was established at our institute in 2008 and has been backcrossed to C57BL/6J mice every two to three years since. Mice were genotyped by PCR on tail snip lysates using the following transgenespecific primers: forward 5'-GGT CAC CCC AAA AAT AAT CTC T-3'; reverse 5'-AGG ATT GGG AAG ACA ATA GC3'. We also amplified a positive control band using the following primers: forward 5'-TCC TCA AAG ATG CTC ATT AG-3'; reverse 5'-GTA ACT CAC TCA TGC AAA GT-3'. Adult male mice were used for all experiments.

\section{Immunohistochemistry}

Tissue preparation

Mice $(n=4)$ were anesthetized (isoflurane) and perfused with cold PBS followed by $4 \%$ paraformaldehyde (PFA). Brains were dissected and immersion fixed in PFA for $24 \mathrm{~h}$ at $4^{\circ} \mathrm{C}$, cryoprotected in sterile $30 \%$ sucrose in PBS for $24-48 \mathrm{~h}$ at $4^{\circ} \mathrm{C}$ or until brains sank, flash frozen in pre-chilled isopentane on dry ice, and stored at $-80^{\circ} \mathrm{C}$. Free floating $35-\mu \mathrm{m}$ brain sections were obtained using a cryostat and kept at $4^{\circ} \mathrm{C}$ in PBS containing $0.01 \%$ sodium azide.

\section{Immunohistochemistry}

Sections were washed in PBS for $10 \mathrm{~min}$ at room temperature (RT) with gentle agitation and then blocked for $1 \mathrm{~h}$ at RT in blocking solution [0.3\% Triton X-100, 1 $\mathrm{mg} / \mathrm{ml}$ bovine serum albumin (BSA), and $5 \%$ normal goat serum (NGS)]. Primary antibody was incubated at $4^{\circ} \mathrm{C}$ overnight with gentle agitation in $0.5 \%$ Tween 20 and $5 \%$ NGS. The following primary antibodies were used: chicken anti-GFP (Abcam, ab13970, RRID:AB_300798; 1:2000), mouse anti-PV (Swant, 235, RRID:AB_10000343; 1:1000), mouse anti-CR (Swant, 6B3, RRID:AB 10000320; 1:500), and mouse anti-CB (Swant, 300, RRID: $\left.A B \_10000347 ; 1: 2000\right)$. Next, sections were triple washed in PBS for 10 min at RT with gentle agitation followed by a 1-h secondary antibody incubation in PBS (in the dark). The following secondary antibodies were used: Alexa Fluor 488 goat anti-chicken (Thermo Fisher Scientific, A-11039, RRID:AB_142924) and Alexa Fluor 568 goat anti-mouse (Thermo Fisher Scientific, A-11004, RRID: $\left.A B \_141371\right)$. Sections were then washed (10 min, RT, three times) and mounted in Vectashield (Vector labs, H1500, RRID:AB_2336788).
Imaging and analysis

Sections were imaged on a Zeiss LSM 780 laser scanning confocal microscope (10× objective, tile scanning of (eA). All microscope settings were kept the same within experiments during image acquisition. Analyst was blind to the identity of the red fluorescent signal (CBP) when performing cell counts, and analysis was performed manually in an unbiased manner at four anterior-posterior levels (equidistant sections located -1.00 through -1.70 $\mathrm{mm}$ from bregma). Data are presented as mean \pm SEM.

\section{In situ hybridization}

\section{Tissue preparation}

Mice ( $n=3-4)$ were anesthetized (isoflurane) and perfused with cold PBS/Z-fix (Fisher Scientific, NC9378601). Brains were dissected and immersion fixed in Z-fix for 24 h at $4{ }^{\circ} \mathrm{C}$, cryoprotected in sterile $30 \%$ sucrose in PBS for $24-48 \mathrm{~h}$ at $4^{\circ} \mathrm{C}$ or until brains sank, flash frozen in prechilled isopentane on dry ice, and stored at $-80^{\circ} \mathrm{C}$. Brains were then sliced on a cryostat in $20-\mu \mathrm{m}$-thick sections, mounted on SuperFrost Plus slides (Fisher Scientific, 1255015) and stored at $-80^{\circ} \mathrm{C}$.

\section{In situ hybridization}

In situ hybridization was performed using RNAscope fluorescent multiplex kit (ACD, 320850) in RNase-free conditions. To perform the RNAscope in situ hybridization, a target retrieval pretreatment protocol was performed as outlined in the manual (ACD, doc. no. 320535). Briefly, slides were submersed in target retrieval buffer (ACD, 322000 ) at $95-98^{\circ} \mathrm{C}$ for $10 \mathrm{~min}$, immediately washed in distilled water, dehydrated with $100 \%$ ethanol (storage at $-80^{\circ} \mathrm{C}$ if required), and lastly digested with Protease IV for $20 \mathrm{~min}$ at $40^{\circ} \mathrm{C}$. Following this pretreatment the RNAScope Fluorescent Multiplex Reagent kit User Manual (ACD, doc.no. 320293) was followed and slides were mounted with DAPI-containing Vectashield (Fisher Scientific, NC9029229). A negative control (ACD, 320751) was run in tandem for each experiment. The probes used from ACD Biotechne were as follows: Crhr1 (418011-C1, -C2), Gad2 (439371-C3), S/c17a7 (416631C2), Penk (318761), Pdyn (318771), Sst (404631), Npy (313321), Prkcd (441791), Crh (316091), and eGFP (400281).

\section{Imaging and analysis}

Slides were imaged on a Zeiss LSM 780 laser scanning confocal microscope $(40 \times$ oil immersion, $1024 \times 1024$, tile scanning of $\mathrm{CeA}$ at approximately bregma $-1.46 \mathrm{~mm}$, $5-\mu \mathrm{m}$ z-stacks). All microscope settings were kept the same within experiments during image acquisition. To perform quantification, ImageJ (Schindelin et al., 2012) was used to outline individual nuclei as identified by DAPI staining and count all nuclei in an unbiased manner (all settings kept the same within experiments). The fluorescence intensity for each probe per DAPI counted nuclei was then measured and the background signal, as determined by the average intensity of the negative control, was subtracted for each channel. For each probe, signal intensity present after background subtraction identified positive nuclei. Experiment was performed in an unbiased manner as probe fluorescence was quantified blindly, 
independently, and after nuclei identification by computational means.

Next, the percentage of nuclei positive for one or both probes and the percentage of signal co-expression were calculated. Percentage of total nuclei was determined by dividing the total number of nuclei expressing that marker by the total number of DAPI positive nuclei per image. The percentage of Crhr1+ nuclei expressing a marker of interest was determined by dividing the number of colabeled nuclei by the total number of Crhr1+ nuclei. The percentage of Crhr1- nuclei co-expressing a marker of interest was determined by dividing the number of cells expressing the marker of interest but not Crhr1 by the total number of Crhr1- nuclei per image. Crhr1+ compared to Crhr1- patterns of co-expression was assessed and normalized to the Crhr1-cells.

For densitometry, signal intensity measured after background subtraction was quantified, log2 transformed, and normalized to the CeL for visualization of the difference in expression. Unpaired Student's $t$ test was used to assess significance of the CeL versus CeM expression difference for each gene, as well as the Crhr1 + to Crhr1- percentage co-expression of each gene. Analysis and statistics were performed using $\mathrm{R}$ programming (R Core Team, 2018). All analyses were performed on raw images. Outliers were detected by Grubb's test. Brightness/contrast and pixel dilation are the same for all representative images shown per figures.

\section{Dendritic spine analysis}

\section{Tissue preparation}

Mice $(n=4)$ were anesthetized (isoflurane) and perfused with cold PBS/4\% PFA. Brains were extracted and immersion fixed in $4 \%$ PFA at $4^{\circ} \mathrm{C}$ for $2 \mathrm{~h}$ before being sectioned coronally into $100-\mu \mathrm{m}$ slices on a vibrating microtome (Leica VT1000S, Leica Microsystems).

\section{Biolistic labeling}

Sections were biolistically labeled with Dil $\left(1,1^{\prime}-\right.$ dioctadecyl-3,3,3', $3^{\prime}$-tetramethylindocarbocyanine perchlorate)-coated 1.1- $\mu \mathrm{m}$ tungsten particles delivered with a Bio-Rad gene gun and incubated in PBS overnight at $4^{\circ} \mathrm{C}$ before immunostaining. Slices were permeabilized in $0.01 \%$ Triton X-100 for 15 min at RT with gentle agitation and blocked for $30 \mathrm{~min}$ at RT with gentle agitation in blocking solution (10\% NGS in $0.01 \%$ Triton X-100). Primary antibody incubation was performed overnight at $4{ }^{\circ} \mathrm{C}$ in PBS (chicken anti-GFP; Abcam, ab13970, RRID: AB_300798; 1:2000). The slices were triple washed with PBS for 10 min followed by secondary antibody incubation for $1 \mathrm{~h}$ at RT in blocking solution (Alexa Fluor 488 goat anti-chicken; Thermo Fisher Scientific, A-11039, RRID: $\left.A B \_142924\right)$. The slices were triple washed in PBS and mounted on slides with Prolong Diamond (Thermo Fisher Scientific, P36965).

\section{Imaging and analysis}

Slides were imaged for CeA on a Zeiss LSM 710 laser scanning confocal microscope (Carl Zeiss Microlmaging; $63 \times$ oil immersion, $1024 \times 1024,1-\mu \mathrm{m}$ step $z$-stacks). All microscope settings were kept the same within experiments during image acquisition. ImageJ (Schindelin et al.,
2012) was used to perform a quantification of filopodia, thin, stubby and mushroom-shaped dendritic spines in both $\mathrm{CRF}_{1}+(n=13$ neurons, 37 dendritic segments) and $\mathrm{CRF}_{1}-$ neurons ( $n=24$ neurons, 41 dendritic segments). The experimenter was blind to cell type $\left(\mathrm{CRF}_{1}+\right.$ vs $\left.\mathrm{CRF}_{1}-\right)$ when performing spine quantification. Data obtained in each mouse were averaged for each cell type, such that the number of mice was used as the $\mathrm{n}$ in statistical analyses. Spine densities and spine type proportions in $\mathrm{CRF}_{1}-$ and $\mathrm{CRF}_{1}+$ neurons were compared using paired $t$ tests. Data are presented as mean \pm standard error. In all cases, $p<0.05$ was the criterion for statistical significance.

\section{Electrophysiological recordings}

Brain slice preparation

Mice $(n=12)$ were briefly anesthetized with $3-5 \%$ isoflurane and decapitated. Brains were rapidly removed and placed in an ice-cold high-sucrose solution $(\mathrm{pH} 7.3-$ 7.4) that contained: $206.0 \mathrm{mM}$ sucrose, $2.5 \mathrm{mM} \mathrm{KCl}, 2.5$ $\mathrm{mM} \mathrm{CaCl}, 7 \mathrm{mM} \mathrm{MgCl}, 1.2 \mathrm{mM} \mathrm{NaH} \mathrm{PO}_{4}, 26 \mathrm{mM}$ $\mathrm{NaHCO}_{3}, 5 \mathrm{mM}$ glucose, and $5 \mathrm{mM}$ HEPES. Brains were cut into coronal sections $(300 \mu \mathrm{m})$ using a Leica $1200 \mathrm{~s}$ vibratome (Leica Microsystems) and placed in oxygenated $\left(95 \% \mathrm{O}_{2} / 5 \% \mathrm{CO}_{2}\right)$ artificial CSF (aCSF) solution composed of the following: $130 \mathrm{mM} \mathrm{NaCl}, 3.5 \mathrm{mM} \mathrm{KCl}, 2 \mathrm{mM}$ $\mathrm{CaCl}_{2}, 1.25 \mathrm{mM} \mathrm{NaH}_{2} \mathrm{PO}_{4}, 24 \mathrm{mM} \mathrm{NaHCO}_{3}$, and $10 \mathrm{mM}$ glucose. Slices were incubated in aCSF for $30 \mathrm{~min}$ at $37^{\circ} \mathrm{C}$, followed by a minimum 30 -min equilibration at RT $\left(21-22^{\circ} \mathrm{C}\right)$ before use.

\section{Electrophysiological recordings}

We visualized neurons using infrared differential interference contrast (IR-DIC) optics and CCD camera (Infinity $3 \mathrm{~s}$, Lumenera). A $60 \times$ magnification water immersion objective (Olympus) was used for identifying and approaching neurons. To avoid photolytic damage, initial exposure to episcopic fluorescence illumination was brief $(<2 \mathrm{~s})$. We detected fluorescent neurons using the Lumen 300 LED system (Prior Scientific) and captured images using Luminera software (Lumenera Corp.). Whole-cell current-clamp and voltage-clamp recordings were obtained with patch pipettes (3-4 M $\Omega$; Warner Instruments) using a Multiclamp 700B amplifier (Molecular Devices), sampled at $20 \mathrm{kHz}$, low pass filtered at $10 \mathrm{kHz}$, digitized (Digidata 1440A; Molecular Devices), and stored on a computer using pClamp 10 software (Molecular Devices). Series resistance was not compensated but monitored throughout the experiment, and cells with a series resistance $>15 \mathrm{M} \Omega$ or $\mathrm{a}>20 \%$ change were excluded.

The intracellular solution used for voltage and current clamp recordings was composed of $145 \mathrm{mM}$ potassium gluconate, $0.5 \mathrm{mM}$ EGTA, $2 \mathrm{mM} \mathrm{MgCl}_{2}$, $10 \mathrm{mM}$ HEPES, 2 $\mathrm{mM} \mathrm{Na}-A T P$, and $0.2 \mathrm{mM}$ Na-GTP. Drugs were dissolved in aCSF and applied by bath perfusion. To isolate sEPSC and $m E P S C$, recordings were performed in the presence of $\mathrm{GABA}_{\mathrm{A}}\left(30 \mu \mathrm{M}\right.$ bicuculline) and $\mathrm{GABA}_{\mathrm{B}}(1 \mu \mathrm{M}$ CGP $55845 \mathrm{~A}$ ) receptor antagonists, and tetrodotoxin (TTX; 0.5 $\mu \mathrm{M})$ was included for mEPSCs. CeA neurons were held at $-60 \mathrm{mV}$ for voltage-clamp recordings and maintained at $-70 \mathrm{mV}$ for current-clamp recordings. 


\section{Drugs and chemicals}

We purchased CGP 55845A (1 $\mu \mathrm{M})$ and CRF (200 nM) from Tocris Bioscience, bicuculline methiodide $(30 \mu \mathrm{M})$ and TTX $(0.5 \mu \mathrm{M})$ from Sigma.

\section{Statistical analysis}

Frequency, amplitude, rise, and decay time of EPSCs were analyzed and visually confirmed using a semiautomated threshold based mini detection software (Mini Analysis, Synaptosoft Inc.). Average EPSC characteristics were determined during baseline and experimental drug conditions in $3 \mathrm{~min}$ bins containing a minimum of 60 events. All detected events were used for event frequency analysis, but superimposed events were eliminated for amplitude and kinetic analysis. Data are presented as mean \pm standard error, and statistical significance was assessed using a two-tailed $t$ test or one-sample $t$ test using Prism 6 (GraphPad Prism). In all cases, $p<0.05$ was the criterion for statistical significance, and $n$ represents the number of cells or mice as indicated.

\section{Results}

\section{Expression of CBPs in CeA $\mathrm{CRF}_{1}+$ neurons}

The CBPs CB, CR and PV label distinct subsets of neurons in the brain and have been widely used as markers of neuronal populations in the amygdala (Andressen et al., 1993; Kemppainen and Pitkänen, 2000). We therefore examined the expression profile of CBPs in $\mathrm{CeA}$ $\mathrm{GFP}+/ \mathrm{CRF}_{1}+$ neurons (Fig. 1). Using immunohistochemistry in $\mathrm{CRF}_{1}$ :GFP mouse brain sections, the coexpression of PV (PV; Fig. 1A), CR (Fig. 1B), and CB (Fig. $1 C, D)$ with GFP was analyzed in the CeA. Of the CBPs labeled, CB was the most widely expressed, while CR was expressed in few cells and PV was virtually absent from the CeA (Fig. 1E). The majority of CeA GFP+ cells were located in the CeM, as described previously (Justice et al., 2008; Herman et al., 2013). The percentage of $\mathrm{CRF}_{1}+$ cells co-expressing each CBP followed the same pattern as the overall counts of CBP + cells, wherein CB was present in $19 \%$, CR was present in $2 \%$, and $P V$ was present in $0.1 \%$ of $\mathrm{CRF}_{1}+$ cells (Fig. $1 F$ ). Based on GFP labeling in $\mathrm{CBP}+$ cells, $\mathrm{CRF}_{1}$ was present in $58 \%$ of $\mathrm{CB}+$ cells and $63 \%$ of $\mathrm{CR}+$ cells, and no PV + cells (Fig. 1G).

\section{Expression of neuropeptides and subpopulation markers in CeA Crhr1+ neurons}

We next examined the expression of subpopulation markers, including neuropeptides, in Crhr1+ neurons in both the CeL and CeM (Fig. 2A). First, the validity of the CRF1:GFP transgenic mice was assessed through the co-expression of GFP mRNA and Crhr1 mRNA in the CeL and $\mathrm{CeM}$ where $58 \%$ and $86 \%$ co-expression in Crhr1+ nuclei and $72 \%$ and $71 \%$ co-expression in GFP mRNA+ nuclei was observed, respectively (Fig. 2B). Additionally, the Crhr1 probe was validated in the septum, a region of low CRF1 expression (Van Pett et al., 2000; Fig. 2C). Glutamic acid decarboxylase 2 (Gad2) and vesicular glutamate transporter 1 (S/c17a7) were used as GABAergic and glutamatergic neuronal markers, respectively. In situ hybridization in both the CeL (Fig. 2D-F) and CeM (Fig. $2 G-I)$ identified a high proportion of nuclei expressing
Gad2, 89\% and 98\%, respectively, and a low proportion expressing S/c17a7, 3\% and 4\%, respectively. This is consistent with the majority of neurons being GABAergic in this region (Pitkänen and Amaral, 1994; Ehrlich et al., 2009). Almost all Crhr1 + cells expressed Gad2 at $98 \%$ in the $\mathrm{CeL}$ and $100 \%$ in the CeM (Fig. $2 E, H$ ), whereas very few expressed S/c17a7 at 6\% in the CeL and 5\% in the CeM (Fig. $2 F, I)$. Additionally, a negative control was run in each series for background subtraction (Fig. 2J). Crhr1 expression was observed in $\sim 23 \%$ and $34 \%$ of all nuclei on average in $\mathrm{CeL}$ and $\mathrm{CeM}$, respectively. These data indicate that CeA Crhr1+ neurons, as well as the vast majority of CeA neurons, are GABAergic and are located in both the CeL and CeM.

Co-expression of Crhr1 with the neuropeptides Penk, Sst, Pdyn, Crh, and Npy, as well as with Prkcd, was also examined (CeL, Fig. 3A-F; CeM, Fig. 4A-F). In the CeL, transcripts for all these genes, except $N p y$, were found in high abundance, where Penk was expressed in $86 \%$ of cells, Sst in 59\%, Pdyn in 58\%, Prkcd in 71\%, Crh in 36\%, and Npy in 5\% of cells (Fig. 3G). The proportion of total nuclei expressing each of these transcripts was similar to the proportion observed in Crhr1+ nuclei only, where Penk was expressed in $92 \%$, Sst in $75 \%$, Pdyn in $70 \%$, Prkcd in 53\%, Crh in 42\%, and Npy in 10\% of Crhr1+ cells (Fig. $3 H$ ). Accordingly, when comparing the expression of the above peptides in CeL Crhr1+ versus Crhr1neurons no significant differences were observed between the two populations (Fig. 3/).

The CeM showed a similar general co-expression pattern as the CeL (Fig. 4A-F). However, the proportion of total nuclei expressing neuropeptides was overall lower, with the percentage expressing Penk at $42 \%$, Sst at $26 \%$, Crh at $18 \%, P d y n$ at $15 \%$, Prkcd at $11 \%$, and Npy at $7 \%$ (Fig. 4G). Similar proportions were observed in Crhr1+ nuclei only, with the percentage expressing Penk at $65 \%$, Sst at $42 \%$, Crh at 27\%, Pdyn at 23\%, Prkcd at $7 \%$, and Npy at $10 \%$ (Fig. 4H). Penk and Sst again presented the strongest co-expression and Npy the weakest. When comparing the expression of the above peptides in CeM Crhr1 + versus Crhr1- neurons, Penk was found significantly enriched in Crhr1+ neurons (1.9-fold, $p=0.004$; Fig. 4/). Lastly, we compared the density of nuclear expression of these co-expressed genes in CeM compared to CeL Crhr1+ nuclei (Fig. 4J), and found that the CeM expressed significantly lower amounts of RNA for all targets [Crh (-1.2-fold, $p=1.2 \mathrm{e}-7)$, Prkcd (-1.84-fold, $p=$ 1.3e-14), Pdyn (-2.3-fold, $p=8.4 \mathrm{e}-11)$, and Sst (-2.95fold, $p=3.8 \mathrm{e}-10)$ ] except Penk, which was expressed at equivalent levels in $\mathrm{CeM}$ and $\mathrm{CeL}$ (-0.07-fold), and Npy (2.7-fold, $p=2.5 \mathrm{e}-7)$, whose mRNA density was higher in CeM. Additionally, we observed that Crhr1 density was higher in the CeM compared to the $\mathrm{CeL}(p=2.2 \mathrm{e}-16$; Fig. 4J).

\section{Dendritic spine morphology and density in $\mathrm{CRF}_{1}+$ and $\mathrm{CRF}_{\mathbf{1}}-\mathrm{CeM}$ neurons}

Higher levels of GFP and Crhr1 mRNA expression were observed in the CeM than in the CeL (Figs. 1-4), as previously reported (Justice et al., 2008; Herman et al., 

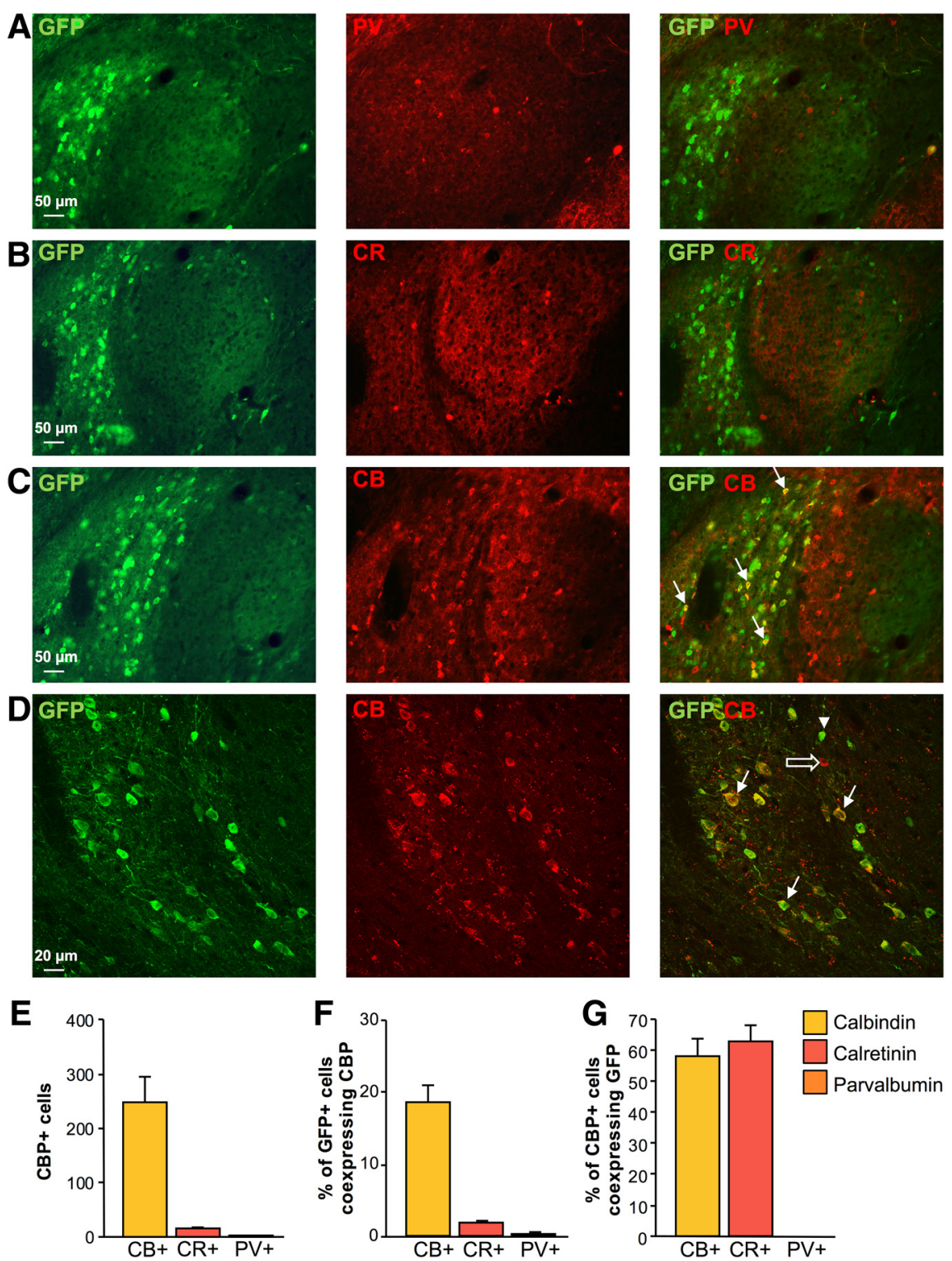

Figure 1. CBP expression in $\mathrm{CRF}_{1}+$ cells in the CeA. Representative images of double immunostaining for GFP and (A) PV (red, GFP $=$ green), $(\boldsymbol{B}) \mathrm{CR}$ (red, GFP $=$ green), and $(\boldsymbol{C}, \boldsymbol{D}) \mathrm{CB}$ (red, GFP $=$ green) in the CeA of $\mathrm{CRF}_{1}$ :GFP mice. Co-expression patterns are visualized in overlaid images in the third column where the arrowhead indicates a single-labeled GFP + cell, the open arrow indicates a single-labeled CB + cell, and filled arrows indicate double-labeled cells that co-express GFP and CB. Scale bars $=50 \mu \mathrm{m}$ $(\boldsymbol{A}-\boldsymbol{C})$ and $20 \mu \mathrm{m}(\boldsymbol{D})$. $\boldsymbol{E}$, Summary bar graph representing the total number of CBP+ cells counted in the CeA. $\boldsymbol{F}$, Bar graph representing the proportion of $\mathrm{CRF}_{1}+$ cells co-expressing each CBP. G, Bar graph representing the proportion of $\mathrm{CBP}+$ cells co-expressing $\mathrm{CRF}_{1}$. Data are shown as mean $\pm \mathrm{SEM}$.

Figure Contributions: $\mathrm{H}$. Sidhu performed the experiments and analyzed the data.

2013). We therefore focused subsequent analyses of $\mathrm{CRF}_{1}+$ and $\mathrm{CRF}_{1}-$ neurons in the CeM. We first analyzed dendritic spines using biolistic labeling of neurons with a lipophilic fluorescent dye followed by GFP immunostaining (Fig. 5A,B). Spine density in $\mathrm{CRF}_{1}+(11$ spines/10 $\mu \mathrm{m})$ neurons was lower than in $\mathrm{CRF}_{1}-(16$ spines/10 $\mu \mathrm{m})$ neurons (paired $t$ test, $t_{(3)}=-3.3, p<0.05$; Fig. $5 C$ ). We further analyzed the morphology of dendritic protrusions and calculated the proportion of mushroom spines, stubby spines, thin spines and filopodia in $\mathrm{CRF}_{1}+(49 \%$, $24 \%, 27 \%$, and $0.7 \%$, respectively) and $\mathrm{CRF}_{1}$ - neurons $(41 \%, 23 \%, 34 \%$, and $1.2 \%$, respectively; Fig. $5 D)$. The proportion of mushroom spines was significantly higher $\left(t_{(3)}=4.9, p<0.05\right)$ while the proportion of thin spines was significantly lower $\left(t_{(3)}=-4.9, p<0.05\right)$ in $\mathrm{CRF}_{1}+$ neurons compared to $\mathrm{CRF}_{1}$ - neurons. There were no differences in the proportion of stubby spines $\left(t_{(3)}=0.4\right.$, n.s.) and filopodia $\left(t_{(3)}=-1.0\right.$, n.s.) between the two cell types.

\section{Glutamatergic transmission in $\mathrm{CRF}_{1}+$ and $\mathrm{CRF}_{1}-$ neurons in the CeM}

We next examined glutamatergic transmission in $\mathrm{CRF}_{1}+$ and $\mathrm{CRF}_{1}-\mathrm{CeM}$ neurons. Before recording gluta- 
A

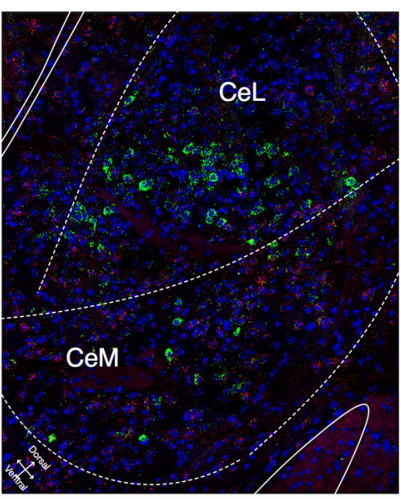

D CeL
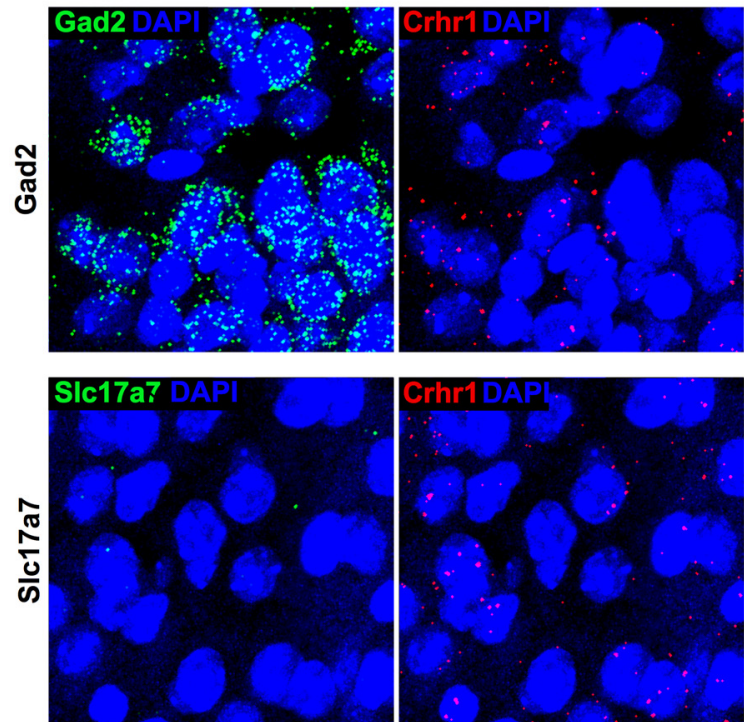

\section{G CeM}
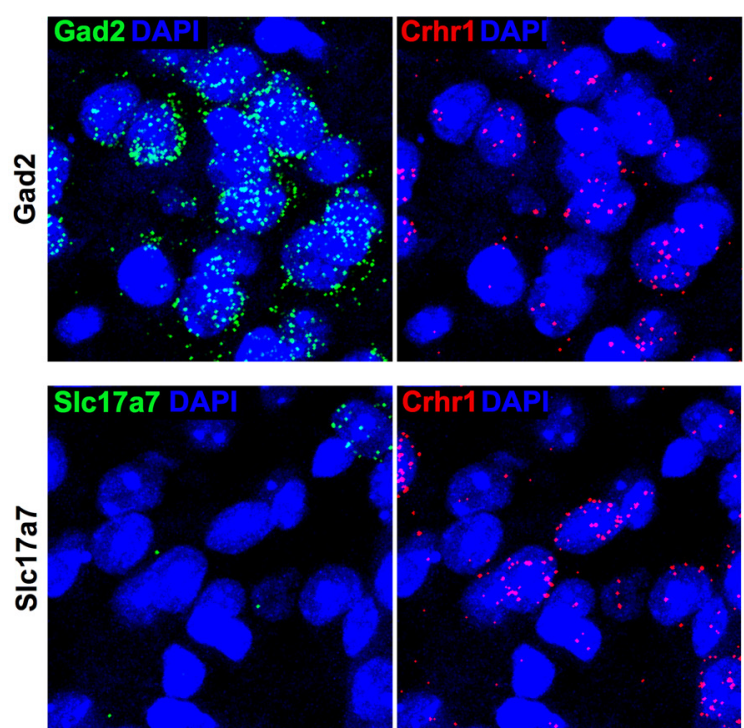

B
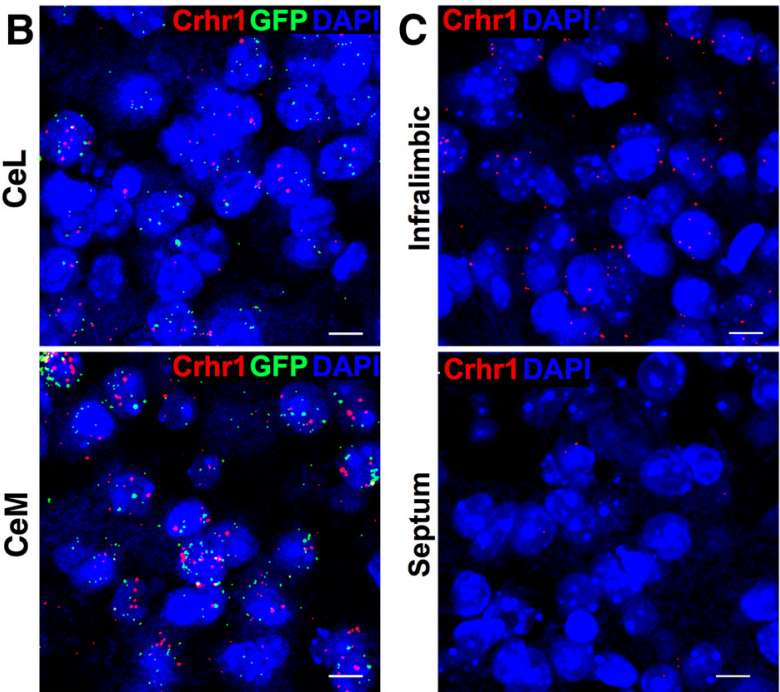

-

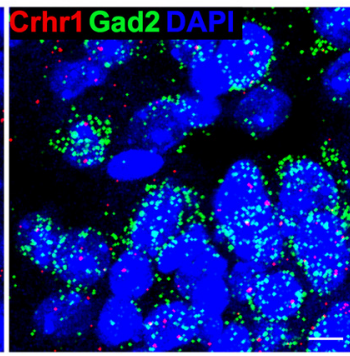

E

$\%$ of Total Nuclei

F $\%$ of $\mathrm{Crhr} 1+$
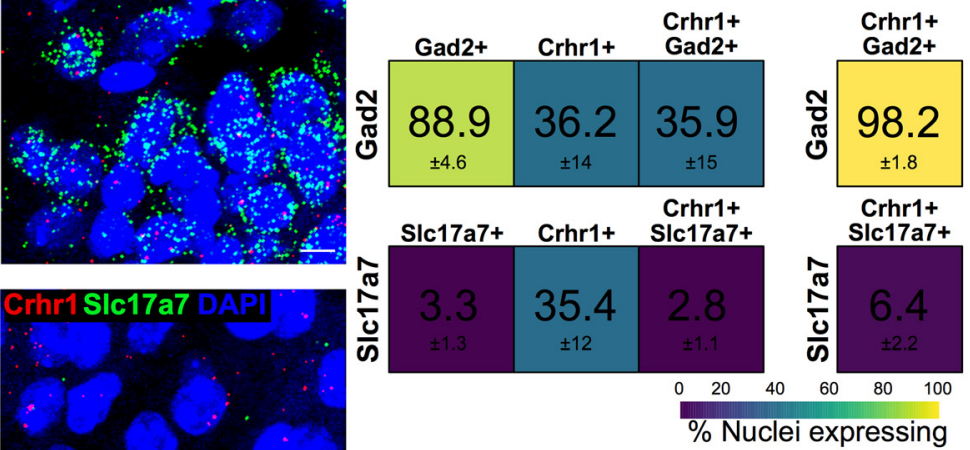

$\%$ Nuclei expressing
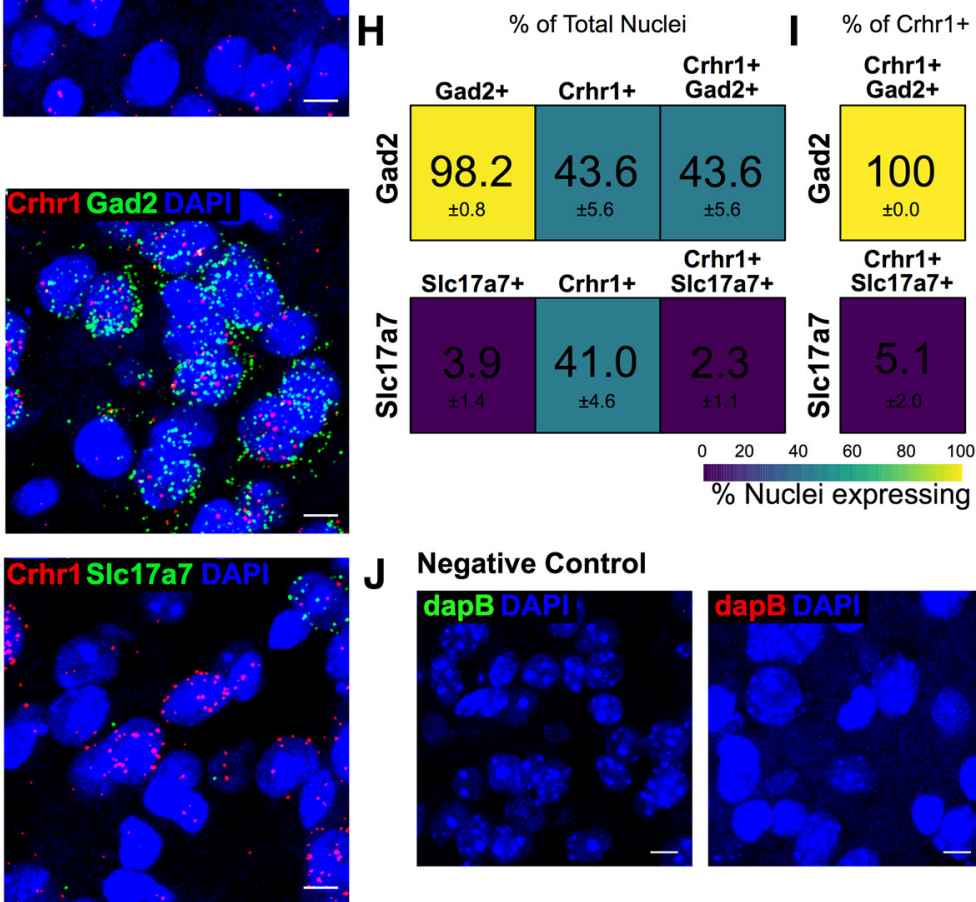

J Negative Control
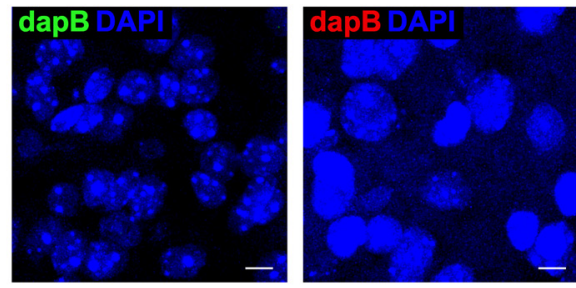

Figure 2. Co-expression of Gad2 or S/c17a7 RNA in Crhr1+ nuclei. A, Schematic of CeA, with CeL and CeM indicated, is overlaid on tiled image of the CeA in which Crh (green), Crhr1 (red), and DAPI (blue) are shown. Image acquisition position of the CeA 
continued

(approximately bregma $-1.46 \mathrm{~mm}$ ) is shown on Nissl stained image (Franklin and Paxinos, 2008) to indicate the region of interest. $\boldsymbol{B}$, Representative images indicate the co-expression of GFP and Crhr1 in the GFP:CRF ${ }_{1}$ mice in CeL (58\%; $n=8$ images) and CeM (86\%; $n=7$ images; Crhr1 = red, GFP = green, DAPI = blue). Scale bar $=10 \mu \mathrm{m}$. C , Crhr1 probe specificity was validated in the septum of wild-type mice, a region of low Crhr1/GFP expression ( $n=2$ images). Negligible expression was observed in the septum as compared to the infralimbic prefrontal cortex in the same slice (Crhr1 = red, DAPI = blue). Scale bar $=10 \mu \mathrm{m}$. $\boldsymbol{D}$, Representative images for Gad2 (upper; green = Gad2, red = Crhr1, blue = DAPI; $n=5$ images) and S/c17a7 (lower; green $=$ Slc17a7, red $=$ Crhr1, blue $=$ DAPI; $n=7$ images) in the CeL. Scale bar $=10 \mu \mathrm{m}$. $\boldsymbol{E}$, Heat map represents the percentage of nuclei expressing (from left to right) RNA of interest, Crhr1, and co-expression in the total nuclei counted in the CeL. $\boldsymbol{F}$, Heat map represents the percentage of nuclei co-expressing in the Crhr1+ population of nuclei in the CeL. Color scale from 100\% (yellow) to $0 \%$ (purple). G, Representative images for Gad2 (upper; green = Gad2, red = Crhr1, blue = DAPI; $n=5$ images) and S/c17a7 (lower; green $=$ S/c17a7, red $=$ Crhr1, blue = DAPI; $n=7$ images) in the CeM. Scale bar $=10 \mu \mathrm{m}$. $\boldsymbol{H}$, Heat map represents the percentage of nuclei expressing (from left to right) RNA of interest, Crhr1, and co-expression in the total nuclei counted in the CeM. I, Heat map represents the percentage of nuclei co-expressing in the Crhr1+ population of nuclei in the CeM. Color scale from 100\% (yellow) to 0\% (purple). Data are shown as mean \pm SEM. $\boldsymbol{J}$, Representative negative control images for the bacterial probe DapB in the CeM indicate negligible fluorescence intensity for both channels shown $(D a p B=$ red, $D a p B=$ green, $D A P I=$ blue $)$. Scale bar $=10 \mu \mathrm{m}$.

Figure Contributions: S. A. Wolfe and S. R. D'Ambrosio performed the experiments. S. A. Wolfe analyzed the data.

matergic activity, whole-cell current clamp recordings with a step protocol consisting of hyperpolarizing to depolarizing current injections were obtained from each cell to determine cell type based on spiking characteristics. As previously described, $\mathrm{CeA}$ neurons are composed of three principal cell types: regular spiking, low threshold bursting, and late spiking neurons (Dumont et al., 2002; Chieng et al., 2006; Herman et al., 2013; Fig. 6A). $\mathrm{CRF}_{1}+$ neurons consisted of only regular spiking and low threshold bursting cell-types as previously reported (Herman et al., 2013, 2016), while the majority of $\mathrm{CRF}_{1}$ - neurons were regular spiking and late spiking neurons (Fig. 6B). No significant differences were observed in the membrane properties of $\mathrm{CRF}_{1}+$ and $\mathrm{CRF}_{1}-\mathrm{CeA}$ neurons (Table 1).

We then assessed baseline glutamatergic transmission using whole-cell voltage clamp recordings of spontaneous action-potential dependent and miniature actionpotential independent EPSCs (sEPSCs and mEPSCs, respectively) in $\mathrm{CRF}_{1}+$ and $\mathrm{CRF}_{1}-\mathrm{CeM}$ neurons (Fig. $6 C-H)$. We observed similar baseline mEPSC frequency $\left(t_{(26)}=1.3\right.$, n.s. $)$ and amplitude $\left(t_{(26)}=1.23\right.$, n.s.) in $\mathrm{CRF}_{1}+$ $(0.9 \pm 0.16 \mathrm{~Hz} ; 30.6 \pm 1.4 \mathrm{pA} ; n=16)$ and $\mathrm{CRF}_{1}$ - neurons $(1.6 \pm 0.5 \mathrm{~Hz} ; 28.0 \pm 1.4 \mathrm{pA} ; n=12$; Fig. $6 C-E)$, and there were no differences in rise and decay kinetics of mEPSCs (Table 2). We also observed similar baseline sEPSC frequency $\left(t_{(26)}=0.75\right.$, n.s.) and amplitude $\left(t_{(26)}=0.70\right.$, n.s.) in $\mathrm{CRF}_{1}+(1.3 \pm 0.3 \mathrm{~Hz} ; 28.9 \pm 0.8 \mathrm{pA} ; n=14)$ and $\mathrm{CRF}_{1}-$ neurons $(1.0 \pm 0.2 \mathrm{~Hz} ; 28.1 \pm 0.6 \mathrm{pA} ; n=14$; Fig. $6 F-H)$, and there were no differences in rise and decay kinetics of sEPSCs (Table 2). Overall, these two populations receive similar glutamatergic input, consistent with their similar density of mature spines.

\section{CRF effects on glutamatergic signaling in $\mathrm{CRF}_{1}+$ and $\mathrm{CRF}_{\mathbf{1}}-\mathrm{CeM}$ neurons}

To assess differences in the functional responsivity of $\mathrm{CRF}_{1}+$ and $\mathrm{CRF}_{1}$ - populations to CRF, we tested the effect of CRF (200 nM; 9-12 min) on mEPSCs (Fig. 6/-N). We found that CRF application increased mEPSC frequency in both $\mathrm{CRF}_{1}+\left(t_{(10)}=2.78, p<0.05\right)$ and $\mathrm{CRF}_{1}-$ $\left(t_{(8)}=2.68, p<0.05\right)$ CeM neurons (Fig. 6J) but did not significantly alter mEPSC amplitude $\left(\mathrm{CRF}_{1}+: t_{(10)}=0.50\right.$, n.s.; $\mathrm{CRF}_{1}-: t_{(8)}=1.12$, n.s.; Fig. $\left.6 K\right)$, rise time $\left(\mathrm{CRF}_{1}+\right.$ : $t_{(10)}=1.28$, n.s.; $\mathrm{CRF}_{1}-: t_{(8)}=0.95$, n.s.; Fig. $\left.6 M\right)$, and decay time $\left(\mathrm{CRF} 1+: t_{(10)}=1.32\right.$, n.s.; $\mathrm{CRF}_{1}-: t_{(8)}=0.85$, n.s.; Fig. $6 N$ ) of mEPSCs in either population (Fig. 6). In summary, CRF globally increases glutamatergic transmission in the CeM via increased presynaptic GABA release, but does not alter mEPSC amplitude or kinetics, suggesting a lack of postsynaptic effect of CRF in either population.

\section{Discussion}

Here, we investigated the neurochemistry, morphology, and physiology of $\mathrm{CRF}_{1}+$ neurons in the $\mathrm{CeA}$ of adult male mice. We found that $C B$ is the predominant $C B P$ expressed in the CeA but overall there is no specific enrichment or exclusion of CBPs in Crhr1+ neurons. Co-expression analysis using in situ hybridization revealed Crhr1 is coexpressed mostly with Penk and Sst and least with Npy. In the CeM, Penk is significantly enriched in $\mathrm{CRF}_{1}+$ neurons compared to $\mathrm{CRF}_{1}-$ neurons. Morphologically, $\mathrm{CRF}_{1}+$ neurons have a lower spine density but a higher proportion of mushroom spines compared to $\mathrm{CRF}_{1}$ - neurons. Accordingly, basal excitatory transmission between $\mathrm{CRF}_{1}+$ and $\mathrm{CRF}_{1}$ - neurons are similar. Additionally, acute CRF application increases glutamatergic transmission in both $\mathrm{CRF}_{1}+$ and $\mathrm{CRF}_{1}$ - neurons. The lack of enrichment or exclusion of any particular CBP or neuropeptide in this population contributes to the difficulty in identifying and studying this subpopulation in this heterogenous region.

\section{CBP and neuropeptide expression in the $\mathrm{CRF}_{1}+$ subpopulation}

GABAergic interneurons may be subcategorized based on their expression of the CBPs PV, CB, and CR, and these distinct subpopulations exhibit unique differences in their physiology, synaptology, and morphology (Kemppainen and Pitkänen, 2000). We found that CB was the predominant CBP in both CeL and CeM nuclei, with only a limited number of neurons expressing PV and CR. This pattern of relative CBP expression is in general agreement with immunohistochemical studies conducted in the rat (Kemppainen and Pitkänen, 2000), and with our previous finding that at least $30 \%$ of $\mathrm{CeA} \mathrm{CRF}_{1}$-expressing neurons project out to the dorsolateral BNST (Herman et al., 


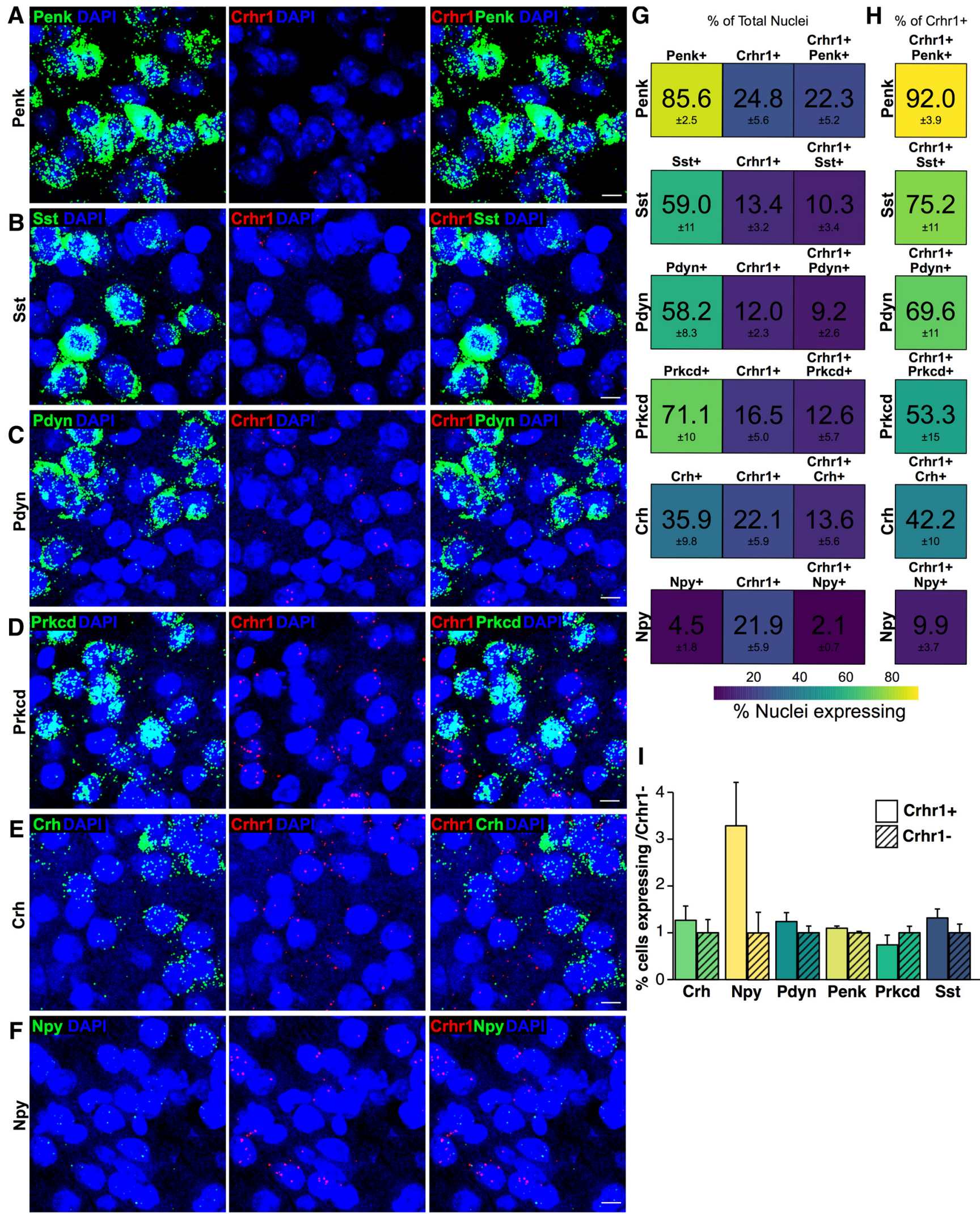

Figure 3. Co-expression of RNA of interest in Crhr1 + nuclei in the CeL. Representative images from top to bottom for $(\boldsymbol{A}) P e n k(g r e e n=P e n k$, red $=$ Crhr1, blue $=$ DAPI; $n=8$ images), (B) Sst (green $=$ Sst, red $=$ Crhr1, blue $=$ DAPI; $n=9$ images), $(\boldsymbol{C}) P d y n$ (green $=P d y n$, red $=C r h r 1$, blue = DAPI; $n=10$ images), (D) Prkcd (green = Prkcd, red = Crhr1, blue = DAPI; $n=9$ images), (E) Crh (green $=C r h$, red $=$ Crhr1, blue $=$ $\mathrm{DAPI} ; n=10$ images), and (F) Npy (green $=N p y$, red $=$ Crhr1, blue $=\mathrm{DAPI} ; n=9$ images) in the CeL. Scale bar $=10 \mu \mathrm{m}$. $\mathbf{G}$, Heat map represents 
continued

the percentage of nuclei expressing (from left to right) RNA of interest, Crhr1, and co-expression in the total nuclei counted in the CeM. $\boldsymbol{H}$, Heat map represents the percentage of nuclei co-expressing in the Crhr1+ population of nuclei in the CeM. Color scale from 100\% (yellow) to 0\% (purple). I, Quantification of the difference between the percentage nuclei expressing RNA of interest (Crh, Prkcd, Pdyn, Npy, Penk, and Sst) in Crhr1+ nuclei versus Crhr1- nuclei in the CeL (mean \pm SEM).

Figure Contributions: S. A. Wolfe performed the experiments and analyzed the data.

$2013,2016)$, one of several downstream brain regions innervated by the CeA.

In addition, CeA neurons can express several neuropeptides that play important roles in fear and anxiety behaviors such as CRF, enkephalins, dynorphins, somatostatin and NPY. The overlapping expression pattern of these neuropeptides differentiates distinct neuronal subpopulations in several brain regions in mice and rats (Petrovich et al., 1996; Herry et al., 2008; Haubensak et al., 2010; Li et al., 2013; Cai et al., 2014; Penzo et al., 2014; Yu et al., 2016; Kim et al., 2017). We hypothesized that $\mathrm{CRF}_{1}$ expression is restricted to a subset of $\mathrm{CeA}$ neurons that co-express a unique combination of neuropeptides. Most of the neuropeptides we investigated had similar trends in the total population compared to the Crhr1+ population. However, Penk was present in a higher proportion of Crhr1+ cells than Crhr1-cells in the CeM. Npy also trended toward an enrichment in Crhr1+ cells over Crhr1- cells in the CeL but co-expression results obtained for this neuropeptide showed more variability than for other markers, most likely due to the small number of Npy+ nuclei. Additionally, densitometry identified a higher expression of Crh, Pdyn, Prkcd, and Sst in the CeL compared to the CeM, which is in agreement with previous studies in mice and rats (Veinante et al., 1997; Day et al., 1999; Marchant et al., 2007; Li et al., 2013; Kim et al., 2017; McCullough et al., 2018). Conversely, Npy was present at higher levels in the CeM than in the CeL.

The enrichment of Penk in CeM Crhr1+ neurons compared to their Crhr1- neighbors may have functional relevance for the recruitment of CeA Penk+ neurons in response to food, drugs and stress. CeA Penk+ are activated by subchronic exposure to fat, ethanol, and nicotine, as well as by withdrawal from morphine in animal models (Criado and Morales, 2000; Veinante et al., 2003; Loughlin et al., 2006; Chang et al., 2014). This activation of CeA Penk+ neurons may result from their preferential expression of $\mathrm{CRF}_{1}$ as some of these stimuli are known to increase $\mathrm{CRF}_{1}$ signaling in the $\mathrm{CeA}$ (Heinrichs et al., 1995; $\mathrm{Nie}$ et al., 2004). Furthermore, chemogenetic activation of CeA Penk neurons produces sustained analgesia, suggesting that $\mathrm{CRF}_{1}$-mediated activation of these neurons could mediate stress-induced analgesia (Wiedenmayer et al., 2002; Paretkar and Dimitrov, 2019).

It is important to consider here that our method for identification of expressing cells is semi-quantitative and that only signal co-localized with DAPI staining after stringent background subtraction was quantified to increase confidence in detection. However, by excluding cell bodies and processes, we lost data concerning dynamic somatic and neurite expression. This method is also limited in its ability to distinguish only neuronal cells which may introduce a consistent level of non-neuronal cells in our analysis. Additionally, co-expression may vary from the rostral to caudal $\mathrm{CeA}$, and a more in-depth study of $\mathrm{CeA}$ neuropeptide localization is necessary to identify the role of these neuropeptides in the $\mathrm{CRF}_{1}+$ subpopulation throughout the CeA. Further studies to identify dynamic expression of RNA or protein at subcellular levels may yield additional information concerning the functional roles of these peptides and proteins.

Our in situ hybridization analysis of Crhr1 expression may yield differing results than GFP expression in the $\mathrm{CRF}_{1}$ :GFP mice due to differences in RNA versus protein expression, sensitivity of the methods used, image acquisition, and identification of GFP saturated soma versus puncta quantification in DAPI-stained nuclei. However, the Crhr1 probe was verified to yield negligible signal in the septum, a region with no $\mathrm{CRF}_{1} /$ GFP expression (Van Pett et al., 2000). Furthermore, our observation that Crhr1 mRNA density is markedly higher in the CeM than in the $\mathrm{CeL}$ is consistent with the patterns of GFP native fluorescence and immunohistochemical staining reported here (Fig. 2B) and previously (Justice et al., 2008; Herman et al., 2013), with GFP expression being substantially more prominent in the CeM than in the CeL. Additionally, probe sensitivity and mRNA abundance might affect the analysis of Crhr1 and GFP mRNA co-expression. A strong overlap was found between both populations in the CeM, as well as a strong co-expression in GFP mRNA+ nuclei in the CeL. However, co-expression was less pronounced in $\mathrm{Crhr} 1+$ nuclei in the CeL, reflective of less GFP protein expression (Fig. 2B). The higher sensitivity of the RNAscope assay compared to native fluorescence and immunohistochemistry probably explains why $\sim 23 \%$ CeL cells are detected as Crhr1+, while a very limited number of CeL cells are identified as GFP+.

\section{$\mathrm{CRF}_{1}+$ neurons differ from $\mathrm{CRF}_{1}-$ neurons in their dendritic morphology}

We characterized the dendritic morphology of $\mathrm{CeA}$ $\mathrm{CRF}_{1}+$ and $\mathrm{CRF}_{1}-$ neurons including spine density and spine shape. The morphology and density of spines plays a crucial role in synaptic and neuronal function. More mature and enlarged spines (mushroom/stubby) are associated with increased synaptic strength, whereas immature spines (thin/filopodia) may sustain limited synaptic signaling (De Roo et al., 2008; Sala and Segal, 2014). Abnormalities in spine morphology are associated with a variety of neurologic and psychiatric disorders, including addiction (Mulholland and Chandler, 2007; Spiga et al., 2014; Phillips and Pozzo-Miller, 2015; Herms and Dorostkar, 2016; Qiao et al., 2016; Varodayan et al., 2018). Previous morphologic characterization of $\mathrm{CeA}$ neurons has identified different cell types (McDonald, 1982; Chieng et al., 2006). Most neurons in the CeM have long 


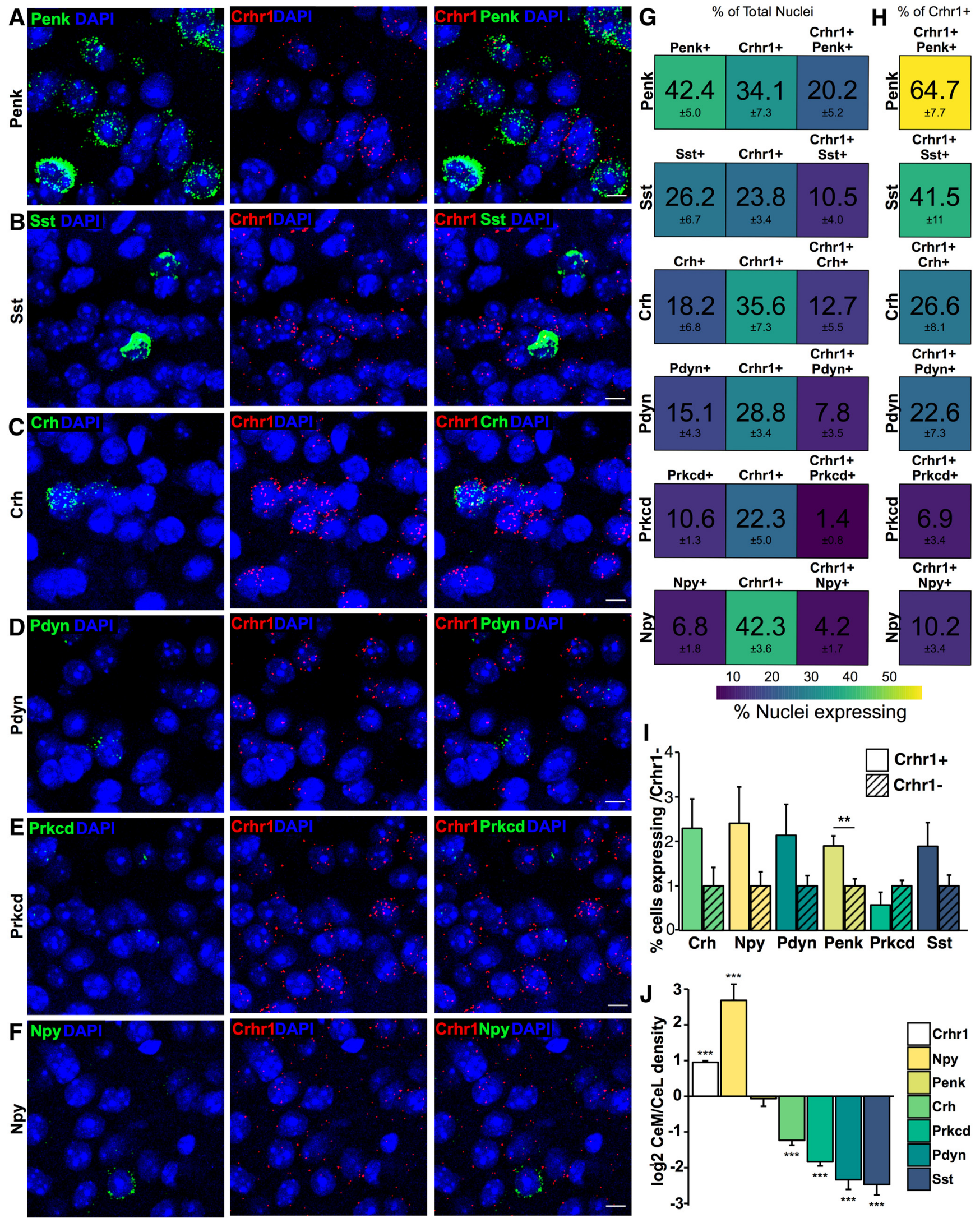

Figure 4. Co-expression of RNA of interest in Crhr1 + nuclei in the CeM. Representative images from top to bottom for (A) Penk (green $=P$ enk, red $=$ Crhr1, blue = DAPl; $n=11$ images), (B) Sst (green $=$ Sst, red = Crhr1, blue = DAPl; $n=10$ images), $(\boldsymbol{C})$ Crh $(g r e e n=C r h$, red $=$ Crhr1, blue = DAPI; $n=11$ images), (D) Pdyn (green $=$ Pdyn, red $=$ Crhr1, blue $=$ DAPI; $n=8$ images), $(E)$ Prkcd (green $=$ Prkcd, red $=$ Crhr1, blue 


\section{continued}

$=\mathrm{DAPI} ; n=6$ images), and $(\boldsymbol{F})$ Npy (green $=$ Npy, red $=$ Crhr1, blue $=$ DAPI; $n=8$ images) in the CeM. G, Heat map represents the percentage of nuclei expressing (from left to right) RNA of interest, Crhr1, and co-expression in the total nuclei counted in the CeM. $\boldsymbol{H}$, Heat map represents the percentage of nuclei co-expressing in the Crhr1+ population of nuclei in the CeM. Color scale from 60\% (yellow) to $0 \%$ (purple). I, Quantification of the difference between the percentage nuclei expressing RNA of interest [Crh, Prkcd, Pdyn, Npy, Penk ( $p=0.004)$, and Sst] in Crhr1 + nuclei versus Crhr1- nuclei in the CeM (mean $\pm \mathrm{SEM}$; $* * p<0.01$ unpaired $t$ test). $\boldsymbol{J}$, Bar graph showing the difference in log2 of the signal intensity between CeL and CeM of Crhr1 ( $n=3079$ nuclei), Npy ( $n=90$ nuclei), Penk ( $n=468$ nuclei), Crh ( $n=273$ nuclei), Prkcd ( $n=276$ nuclei), Pdyn ( $n=141$ nuclei), and Sst ( $n=145$ nuclei) in Crhr1 + nuclei (mean \pm SEM; $* * * p<0.001$ unpaired $t$ test from CeL).

Figure Contributions: S. A. Wolfe performed the experiments and analyzed the data.

dendrites that branch sparingly and have a moderate number of dendritic spines, while a smaller number of neurons have thick dendrites with virtually no spines (McDonald, 1982). Here, we observed that the spine density in $\mathrm{CRF}_{1}+$ neurons was lower than in $\mathrm{CRF}_{1}$ - neurons. We further analyzed the spine type proportions in $\mathrm{CRF}_{1}+$ and $\mathrm{CRF}_{1}-$ neurons and found a higher proportion of mushroom spines and lower proportion of thin spines in $\mathrm{CRF}_{1}+$ neurons. The lower overall spine density is therefore at least partially offset by a higher fraction of mushroom (i.e., most mature) spines, resulting in a comparable density of functional spines in $\mathrm{CRF}_{1}+$ and $\mathrm{CRF}_{1}-$ neurons.

\section{CRF modulation of glutamatergic transmission in $\mathrm{CRF}_{1}+$ versus $\mathrm{CRF}_{1}$ - neurons}

CRF modulates glutamate transmission and has been shown to increase vesicular glutamate release at rat $\mathrm{CeA}$ synapses, which can be enhanced by $\mathrm{CRF}_{1}$ activity (Varodayan et al., 2017). Therefore, we examined glutamatergic transmission in $\mathrm{CRF}_{1}+$ and $\mathrm{CRF}_{1}$ - cells as well as the effect of CRF on glutamatergic transmission in these neu- ronal populations. Both populations receive similar glutamatergic input, consistent with the similar density of functional spines in $\mathrm{CRF}_{1}+$ and $\mathrm{CRF}_{1}-$ neurons. Additionally, CRF increases mEPSC frequency in both populations with no effect on mEPSC amplitude or kinetics in either population. These results are indicative of CRF-induced increased presynaptic GABA release with no postsynaptic effect on glutamatergic receptors.

\section{Conclusion}

Our results reveal molecular, morphologic and functional characteristics of $\mathrm{CRF}_{1}+$ neurons highlighting the importance of identifying specific cell populations in the CeA. The CeA is a hub that integrates disparate inputs (stress) and drives appropriate behavioral outputs. Previous work has demonstrated a major role of the CRF system, and particularly the $\mathrm{CRF}_{1}$ receptors, within the amygdala complex to influence cellular functions that produce maladaptive behavior in animal models. The amygdalar $\mathrm{CRF}_{1}$ system represents a common pathway for the convergence of stress, addiction, pain, depres-

B

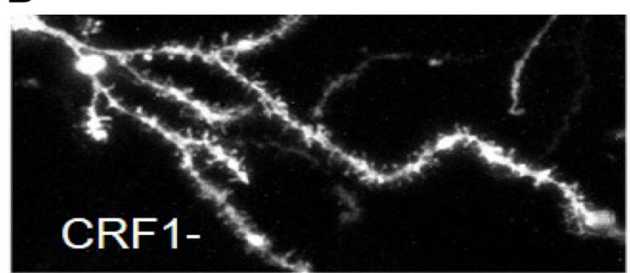

D

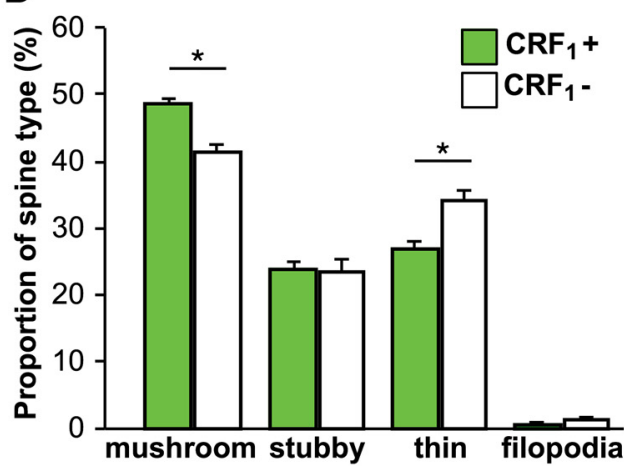

Figure 5. Spine density and morphology of $\mathrm{CRF}_{1}+$ and $\mathrm{CRF}_{1}-$ neurons in the CeA. Representative images of dendritic segments in $\mathrm{CRF}_{1}+(\boldsymbol{A})$ and $\mathrm{CRF}_{1}-(\boldsymbol{B})$ neurons from the CeM of $\mathrm{CRF}_{1}$ :GFP male mice. Scale bar $=10 \mu \mathrm{m}$. $\boldsymbol{C}$, Summary bar graph indicates spine density in $\mathrm{CRF}_{1}+$ and $\mathrm{CRF}_{1}-$ neurons averaged over $10 \mu \mathrm{m}$ dendritic segments $(* p<0.05$ paired $t$ test). $\boldsymbol{D}$, Summary graph indicates proportion of mushroom spines, stubby spines, thin spines and filopodia in $\mathrm{CRF}_{1}+$ and $\mathrm{CRF}_{1}-$ neurons in the $\mathrm{CeA}(* p<0.05$, paired $t$ test). Data are shown as mean \pm SEM $(n=4$ mice).

Figure Contributions: H. Sidhu performed the experiments. H. Sidhu and C. Contet analyzed the data. 
A

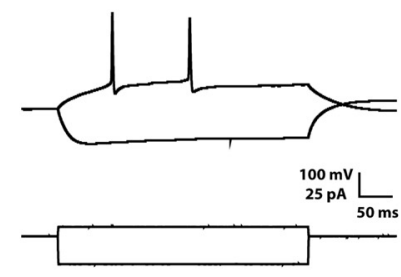

D

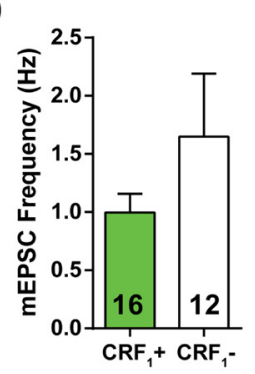

J

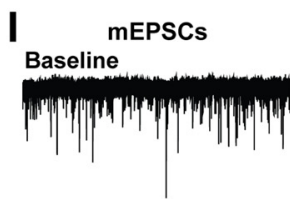

200nM CRF

INPN|
Low Threshold Bursting

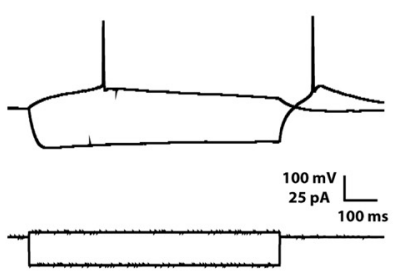

E
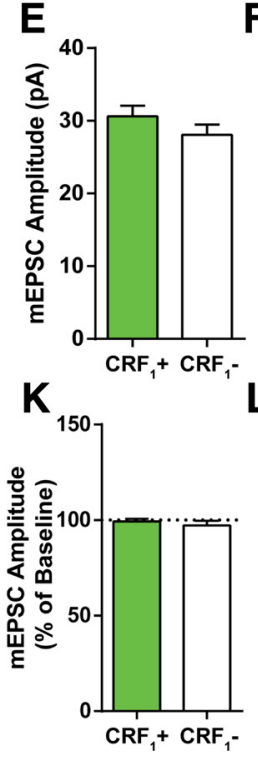

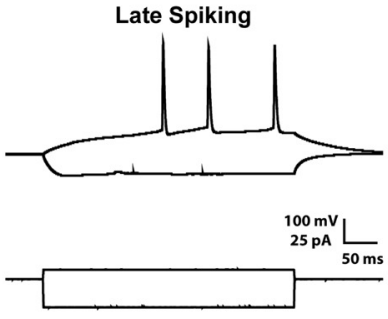

$F$

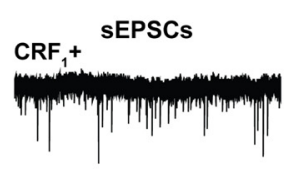

$\mathrm{CRF}_{1}$ -

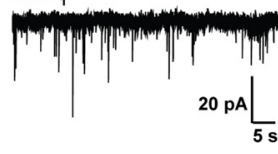

G

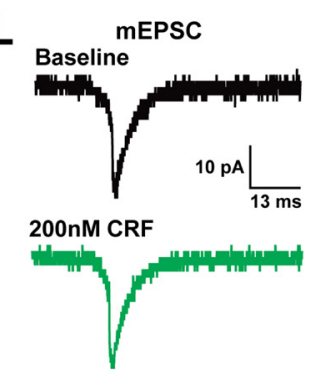

B

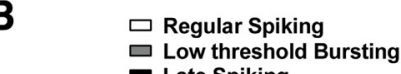

- Late Spiking

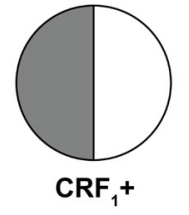

$\mathrm{H}$
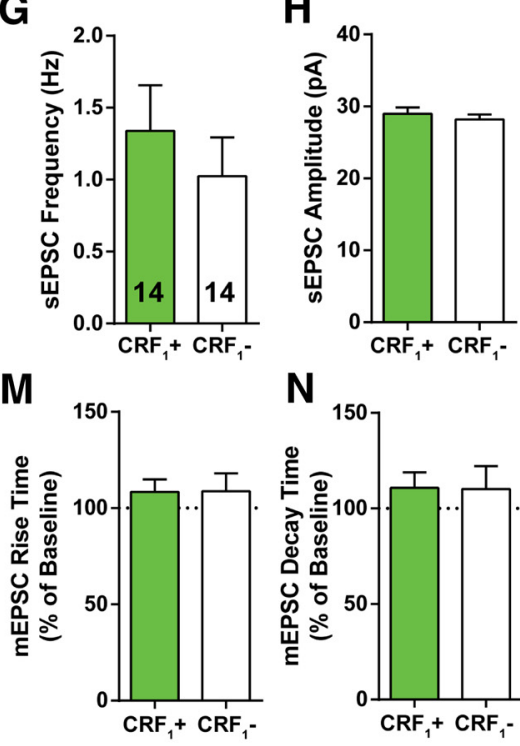

$\mathrm{N}$

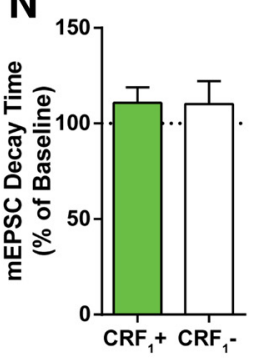

Figure 6. Membrane properties and glutamatergic transmission of $\mathrm{CRF}_{1}+$ and $\mathrm{CRF}_{1}-$ neurons in the $\mathrm{CeA}$. $\boldsymbol{A}$, Representative current-clamp recordings from three cell-types: regular spiking (left), low threshold bursting (middle) and late spiking (right) from a CeA neuron. $\boldsymbol{B}$, Distribution of cell-types recorded from for $\mathrm{CRF}_{1}-(n=15)$ and $\mathrm{CRF}_{1}+(n=16) \mathrm{CeA}$ neurons. $\boldsymbol{C}$, Representative traces of $\mathrm{mEPSC}$ in $\mathrm{CRF}_{1}+$ (top) and $\mathrm{CRF}_{1}-$ (bottom) CeA neurons. $\boldsymbol{D}, \boldsymbol{E}$, Frequency and amplitude of $\mathrm{mEPSCs}$ in $\mathrm{CRF}_{1}+(n=16)$ and $\mathrm{CRF}_{1}-(n=12) \mathrm{CeA}$ neurons. $\boldsymbol{F}$, Representative traces of sEPSCs in $\mathrm{CRF}_{1}+$ (top) and $\mathrm{CRF}_{1}$ - (bottom) CeA neurons. $\boldsymbol{G}, \boldsymbol{H}$, Frequency and amplitude of sEPSCs in $\mathrm{CRF}_{1}+(n=14)$ and $\mathrm{CRF}_{1}-(n=14)$ CeA neurons. I, Representative traces of mEPCS during baseline (top) and $200 \mathrm{nM}$ CRF application (bottom) from $\mathrm{CRF}_{1}+$ CeA neurons. $\boldsymbol{J}, \boldsymbol{K}, \mathrm{CRF}$ effects on frequency and amplitude of mEPSCs in $\mathrm{CRF}_{1}+(n=11)$ and $\mathrm{CRF}_{1}-(n=9) \mathrm{CeA}$ neurons, respectively. $L$, Average trace of mEPSC during baseline (black) and $200 \mathrm{nM}$ CRF (green) application from a $\mathrm{CRF}_{1}+\mathrm{CeA}$ neuron. $\boldsymbol{M}, \boldsymbol{N}, \mathrm{CRF}$ effects on rise and decay time of $\mathrm{mEPSCs}$ in $\mathrm{CRF}_{1}+$ and $\mathrm{CRF}_{1}-\mathrm{CeA}$ neurons, respectively $(* p<0.05$ by one-sample $t$ test). Data are shown as mean \pm SEM.

Figure Contributions: R. R. Patel performed the experiments and analyzed the data.

sion, memory formation and anxiety-related signaling (Koob, 2003, 2008; Zorrilla and Koob, 2004). In particular, $\mathrm{CRF}_{1}$ mechanisms and circuits have been implicated in the development of the negative emotional state associated with alcohol dependence, and it has been proposed that alleviation of this negative state drives the motivation to drink in mice and rats (Funk et al., 2006; Koob, 2010; Roberto et al., 2010; Lowery-Gionta et al., 2012). Our cellular studies revealed that acute and chronic alcohol induced significant alterations in GABAergic signaling in the $\mathrm{CeA}$ circuitry. In addition, this GABAergic signaling is cell type specific for the $\mathrm{CRF}_{1}+$ subpopulation and their connectivity and may contribute to the development of alcohol dependence (Herman et al., 2016).

Our new evidence on the $\mathrm{CRF}_{1}+$ cellular phenotype details the distinct neuronal CeA subpopulations in normal amygdalar function and highlights the need for their further characterization (including intracellular signaling etc) under pathologic conditions, such as alcohol dependence and anxiety disorders. The multiplicity of neuronal subpopulations and the complexity of local microcircuits provide numerous targets for potential dysregulation by

Table 1. Membrane properties of recorded CeA neurons

\begin{tabular}{lllll}
\hline & Membrane capacitance $(\mathrm{pF})$ & Membrane resistance $(\mathrm{M} \Omega)$ & Time constant $(\mathrm{ms})$ & Resting membrane potential $(\mathrm{mV})$ \\
$\mathrm{CRF}_{1}+$ & $44.36 \pm 2.7$ & $476.0 \pm 34.8$ & $369.2 \pm 52.4$ & $-52.1 \pm 1.8$ \\
$\mathrm{CRF}_{1-}$ & $49.91 \pm 2.9$ & $456.2 \pm 13.3$ & $348.4 \pm 55.5$ & $-52.6 \pm 1.8$
\end{tabular}

The membrane capacitance, resistance, time constant, and resting potential are reported for CRF1+ and CRF1- neurons recorded from the CeA. Data are shown as mean \pm SEM.

Table Contributions: R. R. Patel performed experiments and analyzed data. 
Table 2. Summary of mEPSC and sEPSC characteristics

\begin{tabular}{lcccc}
\hline $\begin{array}{c}\text { Frequency } \\
(\mathrm{Hz})\end{array}$ & $\begin{array}{c}\text { Amplitude } \\
(\mathrm{pA})\end{array}$ & $\begin{array}{c}\text { Rise time } \\
(\mathrm{ms})\end{array}$ & $\begin{array}{c}\text { Decay time } \\
(\mathrm{ms})\end{array}$ \\
$\mathrm{mEPSCs}$ & & & & \\
$\mathrm{CRF}_{1}-$ & $1.64 \pm 0.54$ & $28.09 \pm 1.40$ & $0.95 \pm 0.14$ & $0.56 \pm 0.10$ \\
$\mathrm{CRF}_{1}+$ & $0.99 \pm 0.16$ & $30.63 \pm 1.43$ & $1.02 \pm 0.06$ & $0.56 \pm 0.06$ \\
sEPSCs & & & & \\
$\mathrm{CRF}_{1}-$ & $1.02 \pm 0.26$ & $28.18 \pm 0.68$ & $0.84 \pm 0.07$ & $0.60 \pm 0.07$ \\
$\mathrm{CRF}_{1}+1.33 \pm 0.31$ & $28.96 \pm 0.87$ & $0.90 \pm 0.10$ & $0.62 \pm 0.08$
\end{tabular}

The frequency, amplitude, rise time, and decay time of mEPSCs and SEPSCs are reported for CRF1+ and CRF1- neurons recorded from the CeA. Data are shown as mean \pm SEM.

Table Contributions: R. R. Patel performed experiments and analyzed data.

drugs of abuse (e.g., alcohol) and stress, and their potential clinical relevance.

\section{References}

Andressen C, Blümcke I, Celio MR (1993) Calcium-binding proteins: selective markers of nerve cells. Cell Tissue Res 271:181-208.

Baiamonte BA, Valenza M, Roltsch EA, Whitaker AM, Baynes BB, Sabino V, Gilpin NW (2014) Nicotine dependence produces hyperalgesia: role of corticotropin-releasing factor-1 receptors (CRF1Rs) in the central amygdala (CeA). Neuropharmacology 77:217-223.

Binneman B, Feltner D, Kolluri S, Shi Y, Qiu R, Stiger T (2008) A 6-week randomized, placebo-controlled trial of CP-316,311 (a selective $\mathrm{CRH} 1$ antagonist) in the treatment of major depression. Am J Psychiatry 165:617-620.

Bruijnzeel AW, Ford J, Rogers JA, Scheick S, Ji Y, Bishnoi M, Alexander JC (2012) Blockade of CRF1 receptors in the central nucleus of the amygdala attenuates the dysphoria associated with nicotine withdrawal in rats. Pharmacol Biochem Behav 101:62-68.

Cai H, Haubensak W, Anthony TE, Anderson DJ (2014) Central amygdala $\mathrm{PKC}-\delta(+)$ neurons mediate the influence of multiple anorexigenic signals. Nat Neurosci 17:1240-1248.

Chang GQ, Karatayev O, Barson JR, Liang SC, Leibowitz SF (2014) Common effects of fat, ethanol, and nicotine on enkephalin in discrete areas of the brain. Neuroscience 277:665-678.

Chieng BC, Christie MJ, Osborne PB (2006) Characterization of neurons in the rat central nucleus of the amygdala: cellular physiology, morphology, and opioid sensitivity. J Comp Neurol 497: 910-927.

Chu K, Koob GF, Cole M, Zorrilla EP, Roberts AJ (2007) Dependence-induced increases in ethanol self-administration in mice are blocked by the CRF1 receptor antagonist antalarmin and by CRF1 receptor knockout. Pharmacol Biochem Behav 86:813821.

Ciocchi S, Herry C, Grenier F, Wolff SB, Letzkus JJ, Vlachos I, Ehrlich I, Sprengel R, Deisseroth K, Stadler MB, Müller C, Lüthi A (2010) Encoding of conditioned fear in central amygdala inhibitory circuits. Nature 468:277-282.

Criado JR, Morales M (2000) Acute ethanol induction of c-Fos immunoreactivity in pre-pro-enkephalin expressing neurons of the central nucleus of the amygdala. Brain Res 861:173-177.

Cruces J, Venero C, Pereda-Pérez I, De la Fuente M (2014) A higher anxiety state in old rats after social isolation is associated to an impairment of the immune response. J Neuroimmunology 277:1825.

Davis M, Walker DL, Miles L, Grillon C (2010) Phasic vs sustained fear in rats and humans: role of the extended amygdala in fear vs anxiety. Neuropsychopharmacology 35:105-135.

Day HE, Curran EJ, Watson SJ, Akil H (1999) Distinct neurochemical populations in the rat central nucleus of the amygdala and bed nucleus of the stria terminalis: evidence for their selective activation by interleukin-1beta. J Comp Neurol 413:113-128.
De Roo M, Klauser P, Garcia PM, Poglia L, Muller D (2008) Spine dynamics and synapse remodeling during LTP and memory processes. Prog Brain Res 169:199-207.

Dong HW, Petrovich GD, Swanson LW (2001) Topography of projections from amygdala to bed nuclei of the stria terminalis. Brain Res Brain Res Rev 38:192-246.

Dong H, Keegan JM, Hong E, Gallardo C, Montalvo-Ortiz J, Wang B, Rice KC, Csernansky J (2018) Corticotrophin releasing factor receptor 1 antagonists prevent chronic stress-induced behavioral changes and synapse loss in aged rats. Psychoneuroendocrinology 90:92-101.

Dumont EC, Martina M, Samson RD, Drolet G, Paré D (2002) Physiological properties of central amygdala neurons: species differences. Eur J Neurosci 15:545-552.

Dunlop BW, Binder EB, losifescu D, Mathew SJ, Neylan TC, Pape JC, Carrillo-Roa T, Green C, Kinkead B, Grigoriadis D, Rothbaum BO, Nemeroff CB, Mayberg HS (2017) Corticotropin-releasing factor receptor 1 antagonism is ineffective for women with posttraumatic stress disorder. Biol Psychiatry 82:866-874.

Ehrlich I, Humeau Y, Grenier F, Ciocchi S, Herry C, Lüthi A (2009) Amygdala inhibitory circuits and the control of fear memory. Neuron 62:757-771.

Franklin K, Paxinos G (2008) The mouse brain in stereotaxic coordinates, Ed 3. San Diego, CA: Academic Press.

Funk CK, O'Dell LE, Crawford EF, Koob GF (2006) Corticotropinreleasing factor within the central nucleus of the amygdala mediates enhanced ethanol self-administration in withdrawn, ethanoldependent rats. J Neurosci 26:11324-11332.

Funk CK, Zorrilla EP, Lee MJ, Rice KC, Koob GF (2007) Corticotropin-releasing factor 1 antagonists selectively reduce ethanol self-administration in ethanol-dependent rats. Biol Psychiatry 61: 78-86.

Gilpin NW, Herman MA, Roberto M (2015) The central amygdala as an integrative hub for anxiety and alcohol use disorders. Biol Psychiatry 77:859-869.

Haubensak W, Kunwar PS, Cai H, Ciocchi S, Wall NR, Ponnusamy R, Biag J, Dong HW, Deisseroth K, Callaway EM, Fanselow MS, Lüthi A, Anderson DJ (2010) Genetic dissection of an amygdala microcircuit that gates conditioned fear. Nature 468:270-276.

Heilig M, Goldman D, Berrettini W, O'Brien CP (2011) Pharmacogenetic approaches to the treatment of alcohol addiction. Nat Rev Neurosci 12:670-684.

Heilig M, Koob GF, Ekman R, Britton KT (1994) Corticotropinreleasing factor and neuropeptide $\mathrm{Y}$ : role in emotional integration. Trends Neurosci 17:80-85.

Heinrichs SC, Menzaghi F, Schulteis G, Koob GF, Stinus L (1995) Suppression of corticotropin-releasing factor in the amygdala attenuates aversive consequences of morphine withdrawal. Behav Pharmacol 6:74-80.

Herman MA, Contet C, Justice NJ, Vale W, Roberto M (2013) Novel subunit-specific tonic GABA currents and differential effects of ethanol in the central amygdala of CRF receptor-1 reporter mice. J Neurosci 33:3284-3298.

Herman MA, Contet C, Roberto M (2016) A functional switch in tonic GABA currents alters the output of central amygdala corticotropin releasing factor receptor-1 neurons following chronic ethanol exposure. J Neurosci 36:10729-1074.

Herms J, Dorostkar MM (2016) Dendritic spine pathology in neurodegenerative diseases. Annu Rev Pathol 11:221-250.

Herry C, Ciocchi S, Senn V, Demmou L, Müller C, Lüthi A (2008) Switching on and off fear by distinct neuronal circuits. Nature 454:600-606

lemolo A, Blasio A, St Cyr SA, Jiang F, Rice KC, Sabino V, Cottone P (2013) CRF-CRF1 receptor system in the central and basolateral nuclei of the amygdala differentially mediates excessive eating of palatable food. Neuropsychopharmacology 38:2456-2466.

Ji G, Fu Y, Adwanikar H, Neugebauer V (2013) Non-pain-related CRF1 activation in the amygdala facilitates synaptic transmission and pain responses. Mol Pain 9:2. 
Justice NJ, Yuan ZF, Sawchenko PE, Vale W (2008) Type 1 corticotropin-releasing factor receptor expression reported in BAC transgenic mice: implications for reconciling ligand-receptor mismatch in the central corticotropin-releasing factor system. J Comp Neurol 511:479-496.

Kehne JH, Cain CK (2010) Therapeutic utility of non-peptidic CRF1 receptor antagonists in anxiety, depression, and stress-related disorders: evidence from animal models. Pharmacol Ther 128: 460-487.

Kemppainen S, Pitkänen A (2000) Distribution of parvalbumin, calretinin, and calbindin- $\mathrm{D}(28 \mathrm{k})$ immunoreactivity in the rat amygdaloid complex and colocalization with gamma-aminobutyric acid. J Comp Neurol 426:441-467.

Kim J, Zhang X, Muralidhar S, LeBlanc SA, Tonegawa S (2017) Basolateral to central amygdala neural circuits for appetitive behaviors. Neuron 93:1464-1479.e5.

Koob GF (2003) Neuroadaptive mechanisms of addiction: studies on the extended amygdala. Eur Neuropsychopharmacol 13:442-452.

Koob GF (2008) A role for brain stress systems in addiction. Neuron 59:11-34.

Koob GF (2010) The role of CRF and CRF-related peptides in the dark side of addiction. Brain Res 1314:3-14.

Kwako LE, Spagnolo PA, Schwandt ML, Thorsell A, George DT, Momenan R, Rio DE, Huestis M, Anizan S, Concheiro M, Sinha R, Heilig M (2015) The corticotropin releasing hormone-1 (CRH1) receptor antagonist pexacerfont in alcohol dependence: a randomized controlled experimental medicine study. Neuropsychopharmacology 140:1053-1063.

Li H, Penzo MA, Taniguchi H, Kopec CD, Huang ZJ, Li B (2013) Experience-dependent modification of a central amygdala fear circuit. Nat Neurosci 16:332-339.

Lin S, Boey D, Lee N, Schwarzer C, Sainsbury A, Herzog H (2006) Distribution of prodynorphin mRNA and its interaction with the NPY system in the mouse brain. Neuropeptides 40:115-123.

Loughlin SE, Islas MI, Cheng MY, Lee AG, Villegier AS, Leslie FM (2006) Nicotine modulation of stress-related peptide neurons. J Comp Neurol 497:575-588.

Lowery-Gionta EG, Navarro M, Li C, Pleil KE, Rinker JA, Cox BR, Sprow GM, Kash TL, Thiele TE (2012) Corticotropin releasing factor signaling in the central amygdala is recruited during bingelike ethanol consumption in C57BL/6J mice. J Neurosci 32:34053413.

Marchant NJ, Densmore VS, Osborne PB (2007) Coexpression of prodynorphin and corticotrophin-releasing hormone in the rat central amygdala: evidence of two distinct endogenous opioid systems in the lateral division. J Comp Neurol 504:702-715.

McCullough KM, Morrison FG, Hartmann J, Carlezon WA, Ressler KJ (2018) Quantified coexpression analysis of central amygdala subpopulations. eNeuro 5:ENEURO.0010-18.2018.

McDonald AJ (1982) Neurons of the lateral and basolateral amygdaloid nuclei: a Golgi study in the rat. J Comp Neurol 212:293-312.

McGuire JL, Larke LE, Sallee FR, Herman JP, Sah R (2011) Differential regulation of neuropeptide $Y$ in the amygdala and prefrontal cortex during recovery from chronic variable stress. Front Behav Neurosci 5:54.

Menzaghi F, Rassnick S, Heinrichs S, Baldwin H, Pich EM, Weiss F, Koob GF (1994) The role of corticotropin-releasing factor in the anxiogenic effects of ethanol withdrawal. Ann NY Acad Sci 739: 176-184.

Merchenthaler I, Maderdrut JL, Cianchetta P, Shughrue P, Bronstein D (1997) In situ hybridization histochemical localization of prodynorphin messenger RNA in the central nervous system of the rat. J Comp Neurol 384:211-232.

Mulholland PJ, Chandler LJ (2007) The thorny side of addiction: adaptive plasticity and dendritic spines. ScientificWorldJournal 7:9-21.

Nie Z, Schweitzer P, Roberts AJ, Madamba SG, Moore SD, Siggins GR (2004) Ethanol augments GABAergic transmission in the central amygdala via CRF1 receptors. Science 303:1512-1514.
Nielsen DM (2006) Corticotropin-releasing factor type-1 receptor antagonists: the next class of antidepressants? Life Sci 78:909919.

Paretkar T, Dimitrov E (2019) Activation of enkephalinergic (Enk) interneurons in the central amygdala $(\mathrm{CeA})$ buffers the behavioral effects of persistent pain. Neurobiol Dis 124:364-372.

Penzo MA, Robert V, Li B (2014) Fear conditioning potentiates synaptic transmission onto long-range projection neurons in the lateral subdivision of central amygdala. J Neurosci 34:2432-2437.

Petrovich GD, Risold PY, Swanson LW (1996) Organization of projections from the basomedial nucleus of the amygdala: a PHAL study in the rat. J Comp Neurol 374:387-420.

Phillips M, Pozzo-Miller L (2015) Dendritic spine dysgenesis in autism related disorders. Neurosci Lett 601:30-40.

Pitkänen A, Amaral DG (1994) The distribution of GABAergic cells, fibers, and terminals in the monkey amygdaloid complex: an immunohistochemical and in situ hybridization study. J Neurosci 14:2200-2224.

Pomrenze MB, Fetterly TL, Winder DG, Messing RO (2017) The corticotropin releasing factor receptor 1 in alcohol use disorder: still a valid drug target? Alcohol Clin Exp Res 41:1986-1999.

Poulin JF, Castonguay-Lebel Z, Laforest S, Drolet G (2008) Enkephalin co-expression with classic neurotransmitters in the amygdaloid complex of the rat. J Comp Neurol 506:943-959.

Qiao H, Li MX, Xu C, Chen HB, An SC, Ma XM (2016) Dendritic spines in depression: what we learned from animal models. Neural Plast 2016:8056370.

Roberto M, Cruz MT, Gilpin NW, Sabino V, Schweitzer P, Bajo M, Cottone P, Madamba SG, Stouffer DG, Zorrilla EP, Koob GF, Siggins GR, Parsons LH (2010) Corticotropin releasing factorinduced amygdala gamma-aminobutyric acid release plays a key role in alcohol dependence. Biol Psychiatry 67:831-839.

Sala C, Segal M (2014) Dendritic spines: the locus of structural and functional plasticity. Physiol Rev 94:141-188.

Schindelin J, Arganda-Carreras I, Frise E, Kaynig V, Longair M, Pietzsch T, Preibisch S, Rueden C, Saalfeld S, Schmid B, Tinevez JY, White DJ, Hartenstein V, Eliceiri K, Tomancak P, Cardona A (2012) Fiji: an open-source platform for biological-image analysis. Nat Methods 9:676-682.

Schwandt ML, Cortes CR, Kwako LE, George DT, Momenan R, Sinha R, Grigoriadis DE, Pich EM, Leggio L, Heilig M (2016) The CRF1 Antagonist Verucerfont in Anxious Alcohol-Dependent Women: Translation of Neuroendocrine, But not of Anti-Craving Effects. Neuropsychopharmacology 41:2818-2829.

Schwarzer C (2009) 30 years of dynorphins-new insights on their functions in neuropsychiatric diseases. Pharmacol Ther 123:353370.

Spiga S, Mulas G, Piras F, Diana M (2014) The "addicted" spine. Front Neuroanat 8:110.

Spierling SR, Zorrilla EP (2017) Don't stress about CRF: assessing the translational failures of CRF1 antagonists. Psychopharmacology 234:1467-1481.

Sun N, Cassell MD (1993) Intrinsic GABAergic neurons in the rat central extended amygdala. J Comp Neurol 330:381-404.

Sun N, Roberts L, Cassell MD (1991) Rat central amygdaloid nucleus projections to the bed nucleus of the stria terminalis. Brain Res Bull 27:651-662.

R Core Team (2018) R: a language and environment for statistical computing. Vienna, Austria: Foundation for Statistical Computing.

Tye KM, Prakash R, Kim SY, Fenno LE, Grosenick L, Zarabi H, Thompson KR, Gradinaru V, Ramakrishnan C, Deisseroth K (2011) Amygdala circuitry mediating reversible and bidirectional control of anxiety. Nature 471:358-362.

Valdez GR, Zorrilla EP, Roberts AJ, Koob GF (2003) Antagonism of corticotropin-releasing factor attenuates the enhanced responsiveness to stress observed during protracted ethanol abstinence. Alcohol 29:55-60. 
Van Pett K, Viau V, Bittencourt JC, Chan RK, Li HY, Arias C, Prins GS, Perrin M, Vale W, Sawchenko PE (2000) Distribution of mRNAs encoding CRF receptors in brain and pituitary of rat and mouse. $J$ Comp Neurol 428:191-212.

Varodayan FP, Correia D, Kirson D, Khom S, Oleata CS, Luu G, Schweitzer P, Roberto M (2017) CRF modulates glutamate transmission in the central amygdala of naive and ethanol-dependent rats. Neuropharmacology 125:418-428.

Varodayan FP, Sidhu H, Kreifeldt M, Roberto M, Contet C (2018) Morphological and functional evidence of increased excitatory signaling in the prelimbic cortex during ethanol withdrawal. Neuropharmacology 133:470-480.

Veinante P, Freund-Mercier MJ (1998) Intrinsic and extrinsic connections of the rat central extended amygdala: an in vivo electrophysiological study of the central amygdaloid nucleus. Brain Res 794:188-198.
Veinante P, Stoeckel ME, Freund-Mercier MJ (1997) GABA- and peptide-immunoreactivities co-localize in the rat central extended amygdala. Neuroreport 8:2985-2989.

Veinante P, Stoeckel ME, Lasbennes F, Freund-Mercier MJ (2003) c-Fos and peptide immunoreactivities in the central extended amygdala of morphine-dependent rats after naloxone-precipitated withdrawal. Eur J Neurosci 18:1295-1305.

Wiedenmayer CP, Noailles PA, Angulo JA, Barr GA (2002) Stressinduced preproenkephalin mRNA expression in the amygdala changes during early ontogeny in the rat. Neuroscience 114:7-11.

Yu K, Garcia da Silva P, Albeanu DF, Li B (2016) Central amygdala somatostatin neurons gate passive and active defensive behaviors. J Neurosci 36:6488-6496.

Zorrilla EP, Koob GF (2004) The therapeutic potential of CRF1 antagonists for anxiety. Expert Opin Investig Drugs 13:799-828. 